\title{
A spatial explicit scenario method to support participative regional land-use decisions regarding economic and ecological options of short rotation coppice (SRC) for renewable energy production on arable land: case study application for the Göttingen district, Germany
}

Gerald Busch

\begin{abstract}
Background: Renewable energy (RE) production is a land-use driver with increasing impact on landscape configuration and a matter of controversial debate. Woody biomass cropping provides an opportunity to interlink RE supply with spatial planning goals, RE concepts and rural development programmes since it tackles several issues, ranging from climate or soil protection to over food production and income diversification as well as new and additional regional value cluster. Participatory scenario generation supported by interactive visualization tools facilitates the development of joint goals regarding local land-use decisions.

Methods: Based on a stakeholder dialogue in the rural district of Göttingen, two scenarios were quantified and analysed. Reflecting a farmer-oriented economic perspective in (a) "Income first" and an integration of economic and ecological aspects in (b) "Ecological benefits", the two scenarios address opportunities and constraints of poplar short rotation coppice (SRC) in comparison to three common crop rotations in the case study area. Suitable SRC parcels were determined by linking yield modelling results of annual reference crops and poplar SRC with ecological indicators of water-induced soil erosion and ecotone density as well as with annuity calculation and a risk assessment (stochastic dominance) based on the Monte Carlo simulation of price and yield fluctuation.

Results: SRC was economically superior (stochastically first-order dominant) to all three reference crop rotations (oilseed rape-wheat-barley; maize-wheat-maize-wheat; oilseed rape-wheat-wheat) on 1800 ha or $4.9 \%$ of the arable land. With a positive annuity difference ranging between 63 and $236 € \mathrm{ha}^{-1} \mathrm{a}^{-1}$ SRC provides an opportunity to diversify farmers' income. The primary energy supply from the suitable land parcels accounted for $130 \mathrm{GWh} \mathrm{a}^{-1}$ or $8 \%$ of the RE supply in 2030 strived for by local climate protection goals. Around 50\% of the 1800 ha are suitable as focal areas for a joint consideration of farmers' income, erosion protection and structural enrichment. The related average economic trade-off on annuity differences for the gain of substantially increased ecological benefits is about $17 € \mathrm{ha}^{-1} \mathrm{a}^{-1}(13 \%)$.

(Continued on next page)
\end{abstract}

Correspondence: welcome.balsa@email.de

BALSA - Bureau for Applied Landscape Ecology and Scenario Analysis,

Am Weißen Steine 4, 37085 Göttingen, Germany 
(Continued from previous page)

Conclusions: Linking ecological criteria assessment with dynamic investment calculation and risk evaluation in a joint methodology revealed that SRC is an economic viable alternative for renewable energy production and can provide ecological synergies in terms of erosion protection and structural enrichment. The presented methodology is transferrable and allows to visualize stakeholder-based scenarios with an agreed identification of opportunities and constraints that come with SRC on arable land. This helps to better integrate local land-use decisions with formal and informal spatial planning goals.

Keywords: Stakeholder dialogue, Scenario generation, Landscape assessment, Short rotation coppice, Economic return, Monte Carlo simulation, Multi-criteria analysis, Ecological synergies, Arable land management, Erosion protection

\section{Background}

In 2009, the European Union set the agenda to reduce greenhouse gas emission, diminish energy consumption and increase the utilization of renewable energy by $20 \%$ until 2020 in relation to the 1990 levels [1]. The goal setting in Germany was even more ambitious when ratifying a $40 \%$ reduction of greenhouse gas emission and increasing the share of renewable energy consumption to 25-30\% until 2020 [2]. In 2014, the European Council set the binding EU-level target to at least 27\% for the share of renewable energy consumed in the EU in 2030 [3], and Germany is trying to accelerate its energy transition pathway aiming at providing 55 to $60 \%$ of the electricity consumed from renewables by the year 2035 [4].

In 2006, an EEA study [5] estimated that $15 \%$ of projected European energy demand in 2030 could be met with bioenergy derived from European agricultural, forestry and waste products. Referring to the 2014 European Council renewable energy targets, this would translate to a biomass supply share of around $60 \%$. Woody biomass already plays a key role among renewable energy sources, providing around $50 \%$ of the primary production of renewable energy [6]. However, currently, the vast majority of wood resources for renewable energy production originates from forests, whereas lignocellulosic crop production on agricultural land occupies only a small niche with largest wood production from short rotation coppice (SRC) in the UK, Sweden and Poland [7].

In Germany, SRC currently accounts only for 9000 ha of arable land [8] although biomass cropping has been stimulated by the German Renewable Energy Sources Act and its subsequent amendments since 2000 [9]. As a result, a strong increment of energy crop cultivation, especially maize for biogas production and oilseed rape for biodiesel and blending of fossil fuels took place in the last decade. The associated substantial change of landscapes challenges different actors and sectors and needs innovative approaches to integrate sectoral goals.
With around 2.2 Mio ha of agricultural land in 2015 (13.2\%), the spatial demand for energy crop cultivation almost tripled between 2000 and 2015. This rapid and regionally often unbalanced development has caused a considerable increase of land rents and a conversion of pasture to arable land which has raised concern of civic, public and scientific communities (e.g. [10-12]) regarding environmental impacts as well as ethical questions concerning the food production versus fuel cropping on agricultural land.

In this area of conflict, lignocellulosic crops have not become a common feature of agriculture in Germany yet although they do not only provide woody biomass at low $\mathrm{CO}_{2}$ avoidance costs [13-15] but also contribute to sustain several ecosystem services such as erosion protection [16-18], groundwater protection [19], habitat creation [20-23] or structural enrichment [24-26].

Boll et al. [27] conclude from literature studies and regional surveys that apart from economic uncertainties such as the contribution of SRC to income generation, diversification and local added value, the wide range of regulations, laws and perceptions of local authorities hampering a short planning-and approval time is perceived as a major disadvantage of SRC. However, poplar SRC in Germany can be economically competitive to annual crops [28-30] given a proper site selection as well as a suitable business model for the wood chip production. Further, regarding the necessity of an of ongoing substitution of fossil fuels with biomass sources [31-34], lignocellulosic crops as SRC or agroforestry systems (AFS) provide an excellent opportunity to promote decentralized energy supply on a local to regional scale accompanied by environmental and sustainability aspects such as protecting biodiversity, soil fertility or water quality on agricultural land.

Thus, apart from spreading economic success-stories (e.g. $[35,36])$ and transferring scientific knowledge to practice [37], it is crucial to work on participatory communication and decision support strategies with local actors and politics to overcome perception barriers [30, 38, 39] and to trigger local implementation projects. 
Landscape transformation due to the German Renewable Energy Sources Act and the German "Energiewende" (transition from nuclear and fossil fuels to renewable energy supply) is an actual challenge to all German regions [40]. Tackling this challenge is hampered since biomass cropping is subject to several sectoral objectives, e.g. from spatial planning, regional renewable energy concepts and regional rural development programmes such as the EU-funded LEADER initiative [41-43].

A participative scenario generation process supported by interactive visualization tools provides one opportunity to interlink these objectives by facilitating the complex negotiation process between various stakeholder groups and local key players.

A workshop series during the BEST project with more than 100 local actors held in the rural district of Göttingen ("RDG"), Germany, provided the basis for the scenario application presented in this contribution. The major goal identified during this dialogue was to point out the potential of SRC in diversifying local renewable energy production and to find suitable areas for SRC cropping in RDG.

To meet the goals from the stakeholder dialogue, two scenarios (a) "income first" and (b) "ecological benefits" were generated and quantified. The scenario quantification procedure elaborates the methodology laid out for BEAST, the "Bio-Energy Allocation and Scenario Tool" $[29,30,44]$ which was developed during the BEST project (2010-2014, www.best-forschung.de).

Reflecting a farmer-oriented economic perspective in (a) "income first" and an integration of economic and ecological aspects in (b) "ecological benefits", the two scenarios address opportunities and constraints of poplar short rotation coppice (SRC) in comparison to three common crop rotations in the case study area. Suitable SRC parcels were determined by linking yield modelling results of annual reference crops and poplar SRC with ecological indicators of water-induced soil erosion and ecotone density as well as with annuity calculation and a risk assessment (stochastic dominance) based on the Monte Carlo simulation of price and yield fluctuation.

In the results section, suitable areas with respect to the role lignocellulosic crops can play for local renewable energy production, climate protection, sustainable land management issues and farmer's income are identified according to the scenario settings. Results are presented in aggregated form for the RDG and the municipality level. A mapping example illustrates the spatial pattern of suitable SRC sites and depicts synergies and trade-offs on the parcel level. The discussion comprises the appraisal of the approach and leads to the conclusions addressing further options of decision-making support on a local to regional scale.

\section{Methods}

Study area

"RDG" covers around $1118 \mathrm{~km}^{2}, 55 \%$ of which is used for agriculture (Fig. 1). Arable parcels are the spatial reference for this study and account for more than $80 \%$ $(47,000 \mathrm{ha})$ of the agricultural area. The land cover pattern is diverse: a mixture of forest, arable land and pasture constitutes a varied set of mosaic landscapes with the central and eastern region dominated by arable land and the western; hilly part is shaped by larger forest patches. Natural growth conditions for SRC are quite suitable $[45,46]$ in a German context, given an average annual precipitation of around $700 \mathrm{~mm}$ (1981-2010, derived from DWD $1 \mathrm{~km}$ grid information), a mean annual temperature of $8.9{ }^{\circ} \mathrm{C}$ (1981-2010, derived from DWD $1 \mathrm{~km}$ grid information) [47] and a majority of medium to high productive soils $[48,49]$. The location of biogas plants as a potential option to dry wood chips with waste heat was derived from a data compilation persistently published by the German Society for Solar Energy [50] and was cross-checked with the local energy agency.

\section{Stakeholder dialogue and participatory scenario generation}

The interest in SRC as additional source of local renewable energy supply results from ambitious climate protection goals [42]. RDG, as a typical example of German districts, is aiming at reducing their local energy demand and increasing the supply of renewable energy. RDG intends to reduce the energy demand by $30 \%$ until 2030 and to expand the local renewable energy supply to cover $60 \%$ of the energy demand in 2030. Half of this renewable energy supply shall originate from biomass sources.

Various aspects were identified by the stakeholders to define "suitable" sites for SRC. First, as the local farmers' association pointed out, farmers need quantitative information on the economic return of SRC in comparison to the common annual crops of the study area to consider SRC as an option of income diversification. Further, due to the increasing number of biogas plants in the study area, local farmers and energy co-operatives as operators of biogas plants were interested in knowing if using waste heat from biogas for drying of wood chips would be an economically feasible option.

Second, "RDG" is very much exposed to soil water erosion [11] and shows deficits of woody structures in many parts of the agricultural landscape [41]. Therefore, local actors (environmental associations and local nature conservation and planning agency) considered the role SRC could play in erosion prevention and structural enrichment as a very valuable contribution to meet existing planning goals. Third, synergies between economic and 


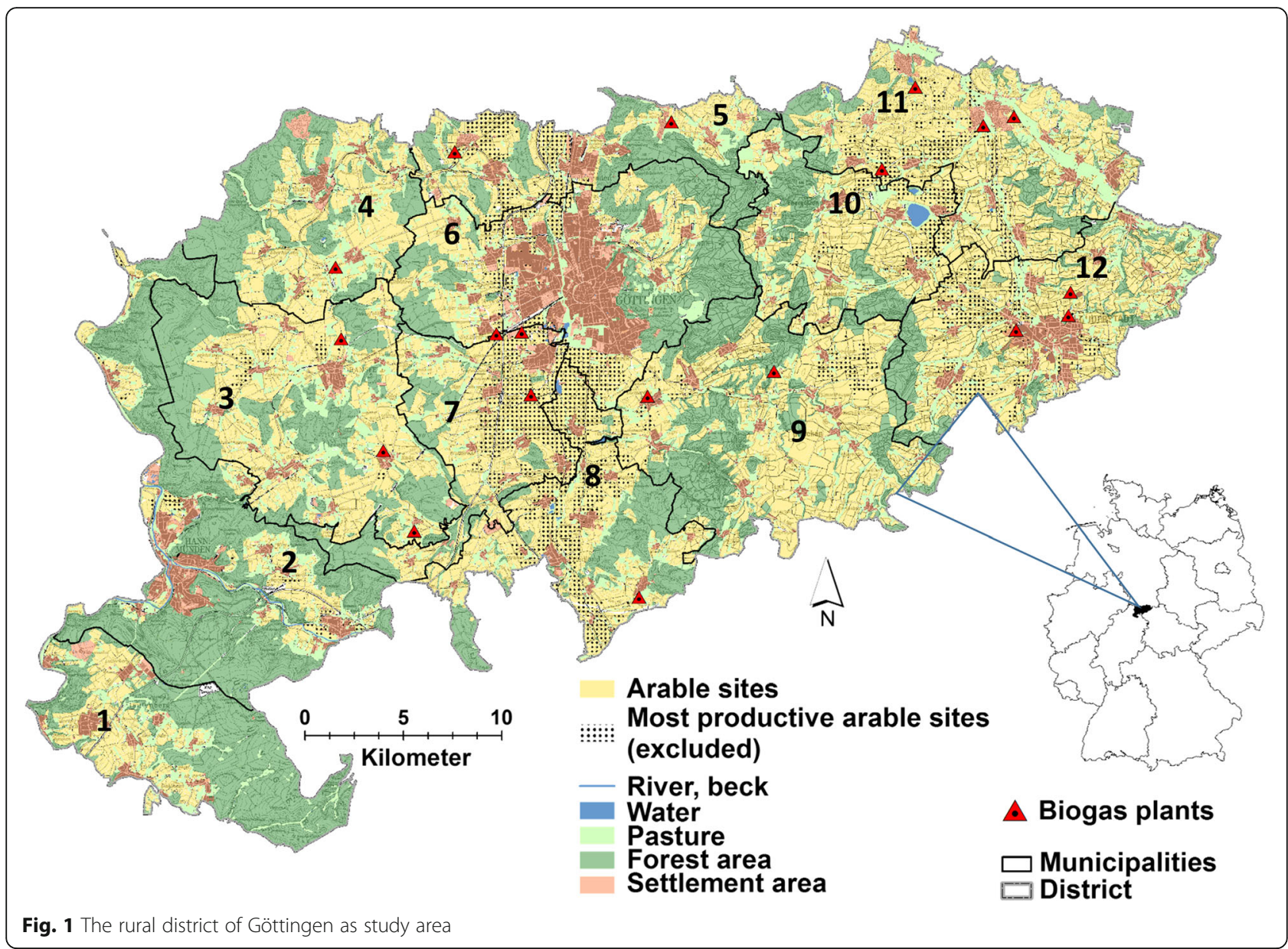

environmental aspects were considered as a key issue for a more integrated land-use concept in the study area. In that respect, it was agreed upon to give the economic return a higher weight within a combined evaluation of the economic and ecological site suitability. Additionally, some spatial allocation rules were formulated: (a) Only arable land was considered for the SRC site selection since the conversion of pasture poses potential environmental concerns [51, 52], (b) SRC should be excluded from NATURA 2000 areas (SPA and SAC), (c) to draw buffer zones around humid-sensitive areas to avoid potential negative impacts due to increased water consumption of SRC [24] and (d) to limit the SRC parcel size and SRC share in agricultural landscapes to avoid negative effects on scenic beauty and biodiversity [26].

As a result of this dialogue two scenarios are quantified in this study. In the "income first" scenario, farmers are the key players. The focus is on finding suitable arable sites to grow lignocellulosic crops for local energy supply which are economically competitive to common local crop rotations.

In scenario 2, "ecological benefits" merges the interests from farmers, spatial planning and climate protection goals by combining competitive economic return from SRC with ecological services provided by SRC, namely erosion protection on erosion-prone arable parcels and structural enrichment in homogenous agricultural landscapes with a lack of woody structures as illustrated by regional spatial planning maps [41].

Both scenarios come with two value-chain alternatives for the farmer: (a) selling-off the fresh wood chips and (b) drying the wood chips with waste heat from biogas plants and selling the dried wood chips.

\section{Scenario quantification}

The scenario quantification for the two scenarios (a) "income first" and (b) "ecological benefits" covers a time period of 20 years. The overall quantification procedure is illustrated by Fig. 2 for the "ecological benefits" scenario. It shows that suitable SRC sites were identified in comparison to annual reference crop rotations by combining quantitative input information with indicatorbased criteria evaluation and spatial filter rules.

To catch the economic perspective of the "income first" scenario, annuities of the selected crop rotations ("The reference cropping systems-comparing a poplar 


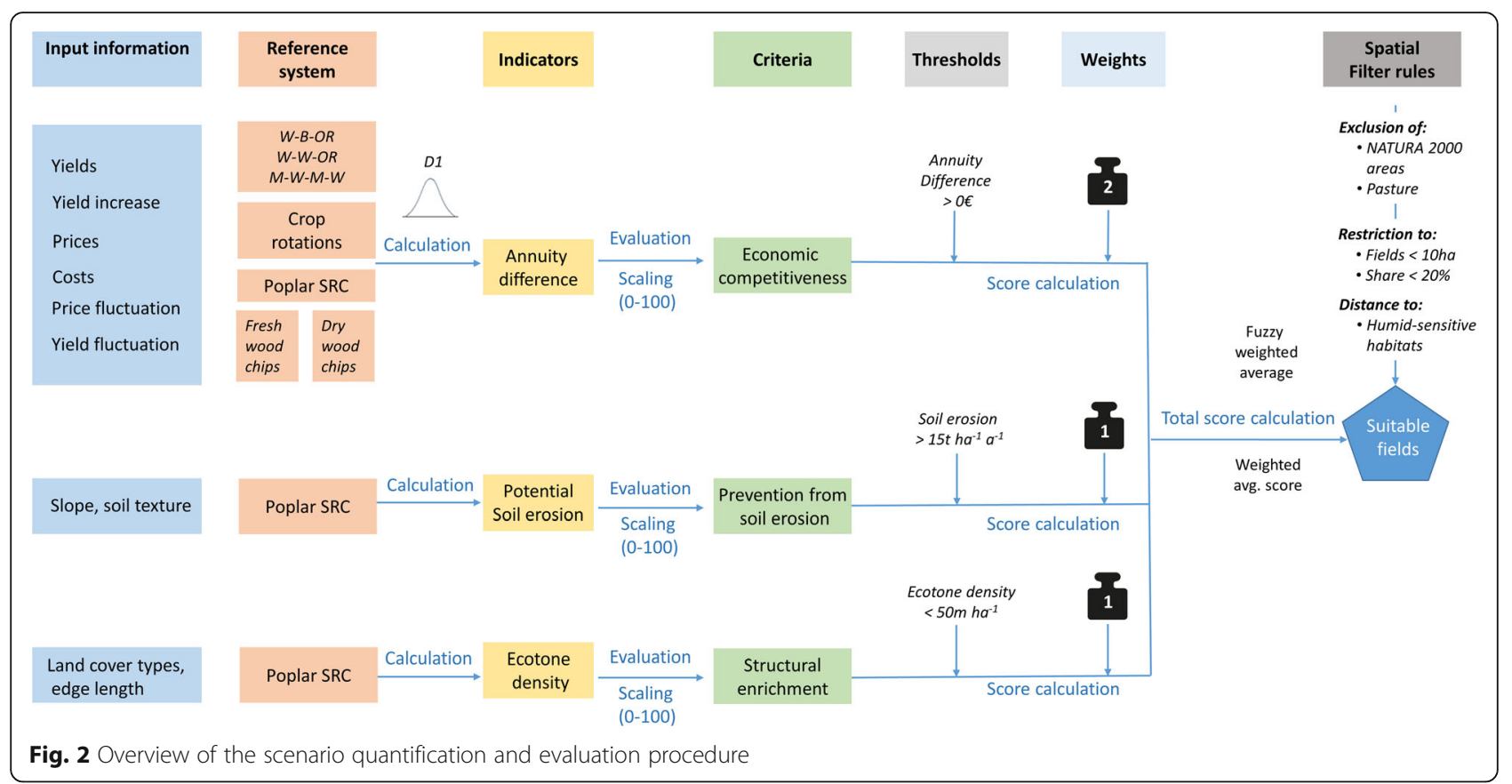

SRC with selected crop rotations" section) and two SRC wood chip production pathways were calculated (see "Wood chip production pathways" and "Yield and yield increase" sections). These annuities ("Annuity calculation"-"Linking annuity calculation with yield and price fluctuations" sections) were subject to a Monte Carlo simulation (MC) with 10,000 variations for each parcel to address their impact of price and yield fluctuations on the economic return. Finally, the concept of stochastic dominance was applied to the MC results ("Selecting economic competitive SRC sites based on the concept of stochastic dominance" section) to identify parcels where SRC is economically superior to the reference crop rotations.

The "ecological benefits" scenario integrates the economic perspective and selected ecological effects of SRC compared to the annual reference crop rotations by addressing the indicators "annuity difference", "potential soil erosion" and "ecotone density" (Fig. 2, and "Potential soil erosion" and "Ecotone density" sections). As part of the multi-criteria assessment, the indicators were evaluated towards the criteria "economic competitiveness", "prevention from soil erosion" and "structural enrichment". The resulting criteria values were weighted to derive the final total score value that expresses the arable parcel suitability (see "Indicator evaluation" section).

The final score was calculated with two approaches to emphasize (a) the average score value and (b) the maximum score of at least one criterion (see "Final score calculation" section). In combination with the designated spatial filter rules ("Applying spatial filter rules" section), the suitable areas were selected.

\section{The reference cropping systems-comparing a poplar SRC} with selected crop rotations

Wheat, oilseed rape, sugar beet, barley and, more recently, maize, are the important annual crops in the rural district of Göttingen [53, 54]. The most prominent crop rotations associated with these crops are "wheatwheat-sugar beet" (WWSB), "oilseed rape-wheat-barley" (ORWB), "oilseed rape-wheat-wheat" (ORWW) and "maize-wheat-maize-wheat" (MWMW).

For the two scenarios presented in this study, a poplar SRC in a 5-year rotation (7000 cuttings) was compared to the three annual crop rotations, (a) "ORWB", (b) "MWMW" and (c) "ORWW", in terms of economic return and effects on soil erosion risk and landscape structure. A comparison between SRC and a "WWSB" rotation is not presented in this study since a preanalysis revealed that this crop rotation economically outcompeted SRC under any circumstances. As a consequence, around 8300 ha was identified as preferable parcels for a "WWSB" rotation by taking soil quality and slope as selection criteria and therefore excluded from the analysis in this study. This number reflects the actual statistics of sugar beet area in a "WWSB" rotation for the Göttingen district [54] and accounts for about 18\% of the arable land total (47,056 ha). The spatial distribution of these sites is depicted in Fig. 1.

\section{Wood chip production pathways}

Two pathways of wood chip production were selected which are at the very beginning of possible supply chains and associated business models (e.g. $[35,55,56])$ a farmer could be part of: (a) sale of fresh wood chips within 
a transport distance of $20 \mathrm{~km}$ and (b) drying the produced wood chips with waste heat from the closest biogas plants and sell the dry chips within a transport distance of $20 \mathrm{~km}$ to these biogas plants.

Both production pathways result in different commodity prices and distinct costs (see "Annuity calculation" and "Linking annuity calculation with yield and price fluctuations" sections). Contrary to pathway (a), there are two transport distances to consider in pathway (b). The first biomass transport distance from the parcel to the biogas plant was calculated in two steps. First, the Euclidean distance between each parcel and the currently existing closest biogas plant (derived from [52]) was measured. Second, the resulting distance was multiplied with a factor of 1.3 representing the average value of a least-cost analysis from 100 randomly selected arable parcels and their road distances [57] to the closest biogas plant. The second transport distance, as in pathway (a), is a fixed distance of $20 \mathrm{~km}$.

\section{Yield and yield increase}

The yield data underlying the scenarios reflect modelling results of average decadal yields (2006-2015) for the annual reference crops (wheat, oilseed rape, barley and maize), whereas the SRC yield data (poplar SRC, 5-year rotation, 7000 saplings) refer to the simulated mean annual increment of woody biomass per rotation period (i.e. four rotation periods for the 20-year-time horizon of the scenarios).

Average annual yields of the annual reference crops were modelled using a multiple linear regression approach which is based on yield levels from field experiments of 52 sites located in Lower Saxony [58]. The model was calibrated with yield data of the Göttingen district and validated with local farm data [26]. The average annual yield increase of the annual reference crops (Table 1) was considered according to updated trend analysis results reported by Busch and Thiele [29]. The results reflect the long-term trends (1976-2015) for the reference crops based on data from national and federal state statistics $[59,60]$.

The SRC yield model for poplar SRC builds on findings by Petzold et al. [61] and is a combination of statistical and empirical functions which refer to available soil water capacity, water balance and temperature as input parameters. The model was modified [26] and calibrated with data from Thuringian long-term field experiments [62, 63] which show soil characteristics and climatic conditions that are comparable to the Göttingen situation.

Details about the yield modelling approaches and the underlying data can be derived from Busch and Thiele [29]. For the energy supply calculation, SRC yields were transformed to numbers of primary energy content by using a conversion factor of $4.95 \mathrm{MWh}$ per oven dry ton $\left(t_{\mathrm{od}}\right)$ of biomass yield according to FNR [64].

\section{Annuity calculation}

Establishing a SRC plantation is a long-term investment with initial as well as final investments and a "delayed" financial return, beginning with the wood chip sale from the first harvesting operation. This is a major difference to annual cropping systems and needs a suitable economic calculation approach. The gross margin calculation, farmers are used to, is not suitable to cover the different timing of payments and revenues in a perennial system like SRC. Therefore, the dynamic capital budgeting approach has to be applied to compare the profit margins of an annual cropping system with a SRC plantation. Annuities, as the result of this calculation approach, represent the average annual profitability and can thus be used for an economic comparison (e.g. [28, 65-67]). The discount rate applied for the annuity calculation was set to $3.5 \%$ for annual crops as well as for SRC. Prices and costs used for the annuity calculation are addressed in the two subsequent sections. To determine the profitability of SRC against the three reference crop rotations, annuity differences were calculated as a result of a Monte Carlos simulation (see "Linking annuity calculation with yield and price fluctuations" section) and a stochastic

Table 1 Reference yield levels as scenario input

\begin{tabular}{|c|c|c|c|}
\hline Item & Description & Reference value & Sources \\
\hline Yield level crops/yield variation ( $\mathrm{dt} \mathrm{ha}^{-1} \mathrm{a}^{-1}$ ) & $\begin{array}{l}\text { Avg. yield level (2006-2015) for } \\
\text { reference crops (model results) } \\
\text { in decitons (dt) in the study area }\end{array}$ & $\begin{array}{l}81.2 \text { (wheat-W) } \\
76.4 \text { (barley—B) } \\
39.4 \text { (oilseed rape-OR) } \\
162.5 \text { (maize-M) }\end{array}$ & Own calculations based on [58] \\
\hline Yield increase crops (\%) & $\begin{array}{l}\text { Trend analysis (1976-2015) of } \\
\text { annual yield increase for reference } \\
\text { crops in the Göttingen district }\end{array}$ & $\begin{array}{l}1.6(\mathrm{~W}) \\
1.5(\mathrm{~B}) \\
1.4(\mathrm{OR} \\
0.3(\mathrm{M})\end{array}$ & Own calculations based on $[59,60]$ \\
\hline Yield level SRC $\left(t_{\text {od }} \mathrm{ha}^{-1} \mathrm{a}^{-1}\right)$ & $\begin{array}{l}\text { Mean annual increment (MAl) over } \\
\text { a } 20 \text {-year period (5-year rotation) for } \\
\text { MAX-1 poplar SRC with } 7000 \\
\text { cuttings in the study area (model results) }\end{array}$ & 11.0 & Own calculations based on [61-63] \\
\hline
\end{tabular}


dominance analysis of the SRC annuities ("Selecting economic competitive SRC sites based on the concept of stochastic dominance" section).

Prices Commodity prices were gathered from regional and national statistics [68-71]. Prices were calculated as net prices without VAT and adjusted for inflation with 2015 as base year (see Table 2). Price averages of the decade from 2006 to 2015 were used as reference which is a conservative approach since the price relation between crop commodities and wood chips is in favour for crop commodities compared to the 2015 situation. Two wood chips commodity price levels were considered (see Table 2) due to the alternative production pathways described in the "Wood chip production pathways" section. The reduced wood chip prices for fresh wood chips reflect maximum drying losses of $20 \%$ derived from [72-75].

Costs Information on crop production costs for the annual reference crops wheat, barley, oilseed rape and maize was derived from annual reports of the Niedersachsen Chamber of Agriculture [70]. Crop production costs were calculated according to KTBL [76] comprising direct costs, and labour and machinery costs.

SRC cost calculation was carried out for five cost positions: (a) site preparation and planting, (b) harvesting operation, (c) transportation in a $20-\mathrm{km}$ radius, (d) storage and drying and (e) re-conversion, by taking their median values from 32 literature sources on German SRC production [28, 65-67, 72-99]. Costs associated with variable transport distances $(0-30 \mathrm{~km})$ as in wood chip production pathway (b) were calculated via a polynomial cost-distance function derived from data of the literature review [28, 65-67, 72-99].

$$
\begin{aligned}
\text { Transport costs }= & -0.0049 \times \text { distance }^{2}+0.6929 \\
& \times \text { distance }+3.1327
\end{aligned}
$$

Yield-sensitive cost positions were calculated via yieldrelated linear functions. Costs which are sensitive to parcel size and slope were further addressed by non-linear functions causing increasing costs with diminishing parcel size, respectively, inclining slopes $[29,51]$.
Table 3 illustrates production costs for average yield levels of the case study region by example of a flat parcel with 5 ha in size.

Linking annuity calculation with yield and price fluctuations As stated by Kröber et al. [67] and Busch [100], economic return of SRC is most affected by yield and price changes (see Appendix: Tables 5 and 6 for sensitivity analysis examples according to Busch [100]). Given a $10 \%$ fluctuation of price and yield levels, Busch and Kröber et al. reported effects on economic return that ranged between 25 and 35\% for annual crops and 15 and $30 \%$ for SRC. This kind of static sensitivity analyses provided valuable information on sensitive parameters-leading to the incorporation of yield-, price-, and yield-increase-fluctuation over time (20 years) as part of the annuity calculation in this study.

To do so, a Monte Carlo simulation with 10,000 iterations was applied to dynamically calculate yield-, price-, and yield-increase-fluctuation for each of the arable parcels. A Gauss distribution with standard deviations from time series trends (2006-2015 for yields and prices and 1976-2015 for yield increase) of these parameters built the boundary conditions for the simulation. Inter-correlations between the fluctuations of commodity prices, yields and yield increase were considered (Table 4).

The resulting annuity data for each of the reference crops as well as for the SRC provided probability distributions which were used to carry out a stochastic dominance analysis $[89,101]$ (see next section).

\section{Selecting economic competitive SRC sites based on the concept of stochastic dominance}

Different decision-makers have distinct attitudes and preferences towards the risk of economic return. According to Maart-Noelck and Musshoff [102], the majority of German farmers are risk-averse. Given an economically efficient decision-making process a risk-averse farmer would opt for SRC if the cumulative probability curve of an SRC annuity ("F") is always below the cumulative probability curve of the corresponding crop rotation annuity ("G"), expressing that the annuity (x) for SRC is higher at any given probability level (see Fig. 3).

Table 2 Commodity prices and price changes for the annual reference crops and wood chips as averages for the decade 2006-2015,

\begin{tabular}{|c|c|c|c|c|c|c|}
\hline Prices $\left[€ t_{o d}^{-1} ; € \mathrm{dt}^{-1}\right]$ & Wood chips (fresh) & Wood chips (dried) & Wheat & Barley & Oilseed rape & Maize \\
\hline Avg. 2006-2015 & $92.8^{*}$ & 116.0 & 18.8 & 16.9 & 37.8 & 18.2 \\
\hline 2015 & $100^{*}$ & 125.0 & 15.9 & 14.0 & 34.3 & 15.3 \\
\hline Price change [\%] & Wood chips (fresh) & Wood chips (dried) & Wheat & Barley & Oilseed rape & Maize \\
\hline Avg. 2006-2015 & 3.0 & 3.0 & 0.3 & 2.2 & -1.1 & -2.2 \\
\hline
\end{tabular}
respectively, for the year 2015 according to national and regional statistics [68-71]

* Wood chips prices reflect drying losses of $20 \%$ 
Table 3 Exemplary production costs for annual reference crops and poplar SRC in the 5-year rotation (7000 cuttings). Costs refer to average yield levels of the case study region (see Table 1)

\begin{tabular}{llll}
\hline Item & Description & Reference costs & Sources \\
\hline Crop production costs $(€)$ & Yield-specific (avg. yield level) production costs & $1118(\mathrm{~W})$ & Own calculations based \\
& & $979(\mathrm{~B})$ & $1128(\mathrm{OR})$ \\
on [26, 59] & $1177(\mathrm{M})$ & Own calculations based \\
SRC production costs $(€)$ & Preparation and planting & 2107 & on [26, 28, 43, 65-67, 72-99] \\
& Harvesting and chipping & 880 & 825 \\
& Transportation (20 km) & 356 & \\
& Transportation variable distances (here 5 km) & 385 & $1900(1600+300)$ \\
& Storage and drying with waste energy from biogas plants & \\
& Re-conversion (incl. fertilizer application) &
\end{tabular}

In the concept of stochastic dominance, this case is called first-order stochastic dominance of the SRC annuity. To apply the concept of stochastic dominance, the annuity results from the Monte Carlo simulation were sorted in ascending order for each crop rotation and for SRC. This procedure was carried out for each of the 19,000 parcels. A stochastic first-order dominant ("D1") situation was identified on these parcels where all annuity differences were positive when subtracting the sorted SRC annuities from the sorted crop rotation-specific annuities.

Consequently, the averaged annuity differences of the "D1" parcels were used as economic indicator for the indicator evaluation ("Indicator evaluation" section) and is referred to as "D1 SRC annuity difference".

\section{Potential soil erosion}

Potential soil erosion risk was calculated for each agricultural parcel by applying reference methodologies for soil assessments from the federal state agency of Lower Saxony [103]. These methodologies in turn are based on the German adaptation [104] of the "Revised Universal Soil Loss Equation" [105] taking into account soil texture information from the "Reichsbodenschätzung" (German Soil Survey - 1:5,000) and slope angles from a digital elevation model with a resolution of $12.5 \mathrm{~m}$. Details can be derived from Schäfer et al. [106].

\section{Ecotone density}

Ecotone density was calculated for agricultural landscapes surrounding each arable parcel in a $250-\mathrm{m}$ radius - with agricultural landscapes defined by agriculture as the dominating land cover $(>50 \%$ of the area covered in the search radius). Within each radius of the arable parcels, lengths of woody edges were summarized and divided by the area total to get the density measure "ecotone density". German ATKIS (Official Topographic Information System) data (1:25,000) and its land cover classification [57] in combination with the mapping of "woody structures outside forests" provided by Seidel et al. [107] were the underlying data sources to determine the ecotone density indicator.

\section{Indicator evaluation}

The three indicators "annuity difference", "potential soil erosion" and "ecotone density" were evaluated towards the criteria "competitive economic return", "prevention from soil erosion" and "structural enrichment" according to the scenario goals. For each criterion, an evaluation function was generated that covers the value range from 0 to 100 (see Figs. 4 and 5).

Based on the "D1 SRC annuity difference", "competitive economic return" was described via a ramp function with a "D1 SRC annuity difference" of $0 € \mathrm{ha}^{-1} \mathrm{a}^{-1}$ as minimum and $200 € \mathrm{ha}^{-1} \mathrm{a}^{-1}$ as maximum of the function (see Fig. 4). A medium competitive economic return

Table 4 Input values for the Monte Carlo Simulation of yield-, price-, and yield increase fluctuation. SRC wood chips price (a) relates to SRC production pathway (a) and price (b) to production pathway (b)

\begin{tabular}{|c|c|c|c|c|c|}
\hline & Wheat & Barley & Oilseed rape & Maize $(33 \% \mathrm{dm})$ & SRC \\
\hline Average yield $\left[d t, t_{\text {od }}\right](2006-2015)$ & 81.2 & 76.4 & 39.4 & 162.5 & 11 \\
\hline Standard deviation & 6.3 & 6.9 & 4.4 & 9.5 & 1.1 \\
\hline Average commodity prices $\left[€ \mathrm{dt}^{-1}, € t_{\mathrm{od}}^{-1}\right](2006-2015)$ & 18.8 & 16.9 & 37.8 & 3.4 & $116.0(a), 92.8(b)$ \\
\hline Standard deviation & 3.9 & 3.8 & 7.5 & 0.4 & 12.4 \\
\hline Average yield increase [\% $\left.\mathrm{a}^{-1}\right]$ (1976-2015) & 1.6 & 1.5 & 1.4 & 0.3 & 0 \\
\hline Standard deviation & 0.18 & 0.20 & 0.18 & 0.02 & 0 \\
\hline
\end{tabular}




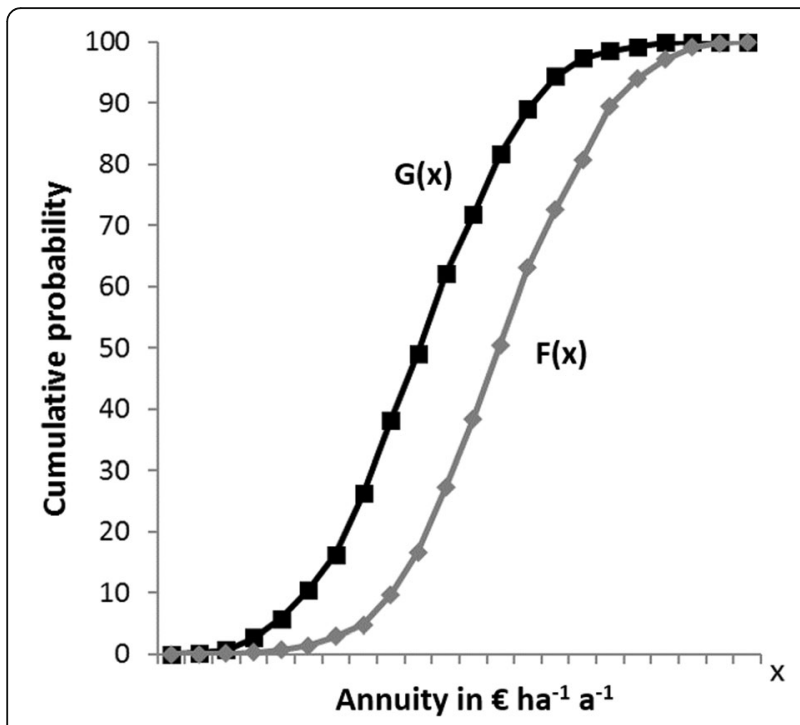

Fig. 3 The concept of stochastic dominance-illustrating a first-order stochastic dominance of $F(x)$ over $G(x)$

was assigned to a "D1 SRC annuity difference" of $100 €$ since this reflects a risk premium for SRC in comparison to annual crops as reported by Ericson et al. [108]. The "D1 SRC annuity difference" of $200 € \mathrm{ha}^{-1} \mathrm{a}^{-1}$ was selected as upper threshold because it covers the potential loss of revenue due to low prices combined with low yields from the static sensitivity analysis by Kröber [67] and Busch [100].

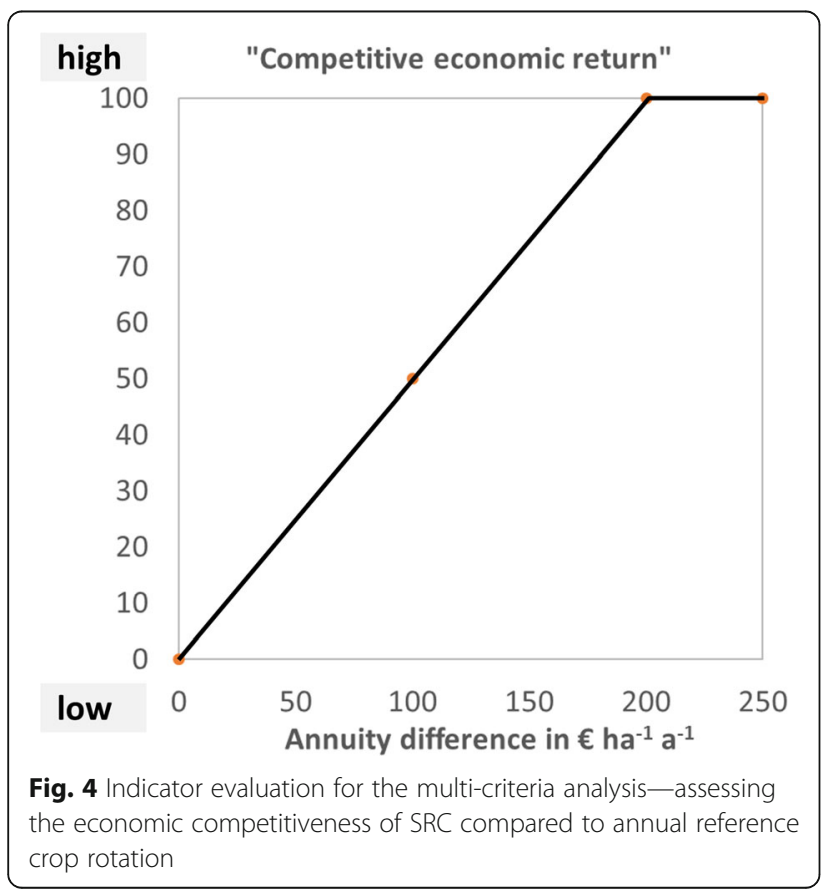

Thresholds based on the EU cross-compliance regulations were used [109] to evaluate the SRC potential to provide prevention from soil erosion. According to these regulations, farmers have to take protective measures on arable parcels with a potential soil erosion risk higher than $15 t \mathrm{ha}^{-1} \mathrm{a}^{-1}$. The minimum (" 0 ") and maximum values (" 100 ") of the evaluation function relate to zero, respectively, $25 \mathrm{tha}^{-1}$ of "potential soil erosion" (see Fig. 5), and reflect the risk classification of the Federal State Agency for Mining, Geology and Energy of Lower Saxony [104]. Note that for the multicriteria assessment, only areas with a potential soil erosion risk greater than $15 \mathrm{tha}^{-1} \mathrm{a}^{-1}$ were considered to address the cross-compliance regulations (see Fig. $5 \mathrm{a}$ also).

Agricultural landscapes with low ecotone densities will profit from the enrichment with woody structures provided by SRC [24-26]. Priority areas for structural enrichment as identified by regional planning for the rural district of Göttingen [42] were used as reference to derive the minimum and maximum values for the evaluation function of "ecotone density" (see Fig. 5b). With ecotone density values ranging between 7 and $50 \mathrm{~m}$ ha ${ }^{-1}$ in these priority areas, the evaluation function for SRC was shaped in a way that maximum structural enrichment potential was assigned to a density value lower than $10 \mathrm{~m} \mathrm{ha}^{-1}$. The lower threshold was set to an ecotone density of $50 \mathrm{~m} \mathrm{ha}^{-1}$. Only ecotone densities lower than $50 \mathrm{~m} \mathrm{ha}^{-1}$ were considered for the multicriteria calculation.

\section{Final score calculation}

Two procedures, (a) the weighted average score calculation and (b) the fuzzy weighted maximum calculation, were applied to carry out the multi-criteria analysis. With the weighted average score method, the evaluation values of the three criteria were multiplied with their specific weight and averaged over the value sum by taking the weight sum into account. The ordered weighted fuzzy averaging builds on procedure (a) by multiplying each criterion considered with its specific weight but orders the results and applies an order weight $\alpha$ as exponent $[110,111]$. The rationale behind this procedure is to vary the logic when combining the criteria. Low-order weights strongly select the high-ranked values of the input criteria while high-order weights support the low-ranked values. An order weight of 1 simply represents method (a). For this study, low-order weights were applied to pick the maximum criterion values for the selection of suitable parcels.

\section{Applying spatial filter rules}

Spatial filter rules provide an additional opportunity to steer the selection of suitable SRC parcels. For this 

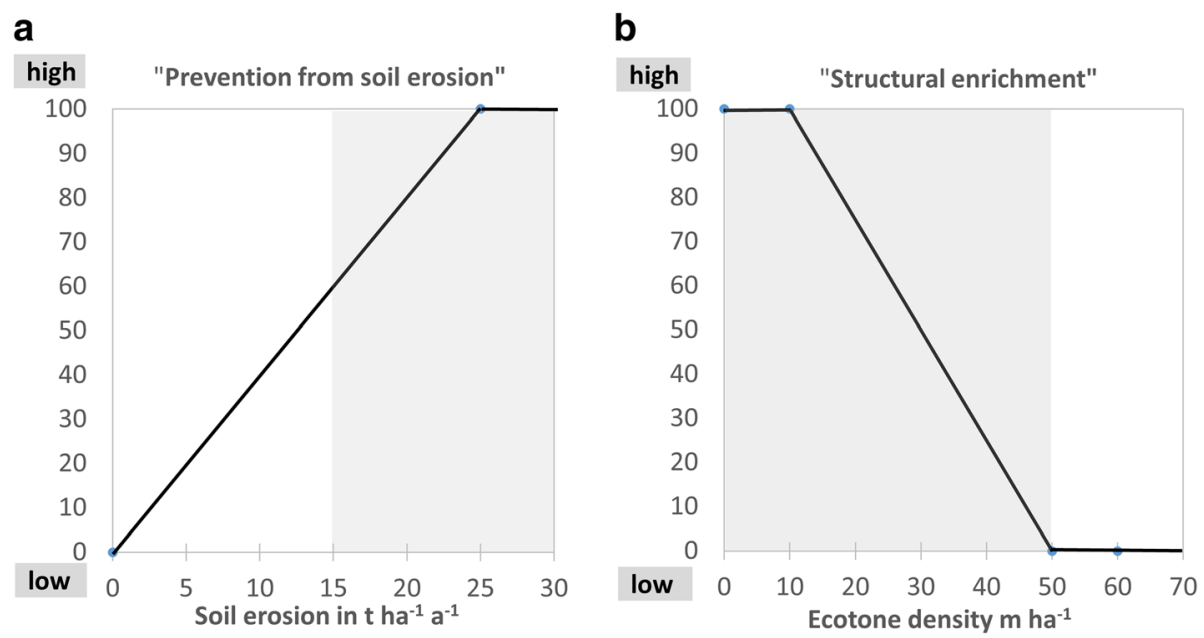

Fig. 5 Indicator evaluation for the multi-criteria analysis—assessing the potentials of SRC for "prevention form soil erosion" (a) and "structural enrichment" (b) compared to annual reference crop rotation. Grey corridors indicate the range of values that were considered for the final score calculation (see "Final score calculation" section)

study, five spatial filter rules were applied. Environmental issues are addressed by drawing buffer zones with a diameter of $200 \mathrm{~m}$ around humid-sensitive areas [112] and excluding SRC from NATURA 2000 areas (SPA and SAC) [51, 52]. Only arable land was considered for the SRC site selection since the conversion of pasture poses potential environmental concerns $[52,113]$. Further, parcel selection was limited to a maximum SRC share of $20 \%$ for each municipality and to a maximum parcel size of 10 ha to avoid negative effects on scenic beauty and biodiversity [26].

\section{Results}

The results section is subdivided in three parts showing parcel suitability findings on different spatial levels by comparing the two scenarios including their two production pathways. The "Suitable "D1" SRC areas-results for the district level" section covers the aggregated results on the district level, whereas the "Identifying synergies and trade-offs on the municipality level" section addresses the variation of results on the municipality level, and the "Identifying synergies and trade-offs on the parcel level" section focuses on synergies and trade-offs on the parcel level.

\section{Suitable "D1" SRC areas-results for the district level}

The district level results are depicted in aggregated form in Fig. 6. The main objective of the figure was to compare the suitable SRC parcels to the reference crop rotations as well as to the combination of all three reference crop rotations with respect to (1) area sum, (2) energy supply, (3) avg. annuity difference,
(4) ecotone density and (5) soil erosion. For this purpose, the two scenarios as well as their production pathways were compared to each other. The absolute numbers were presented in spider diagrams, whereas the relative differences between the scenarios, respectively, between the production pathways were highlighted in the vertical and horizontal bar graphs. Note that suitability for both scenarios implies the "D1 annuity difference".

\section{Overall analysis}

The general picture, valid for both scenarios and their production pathways on the district level, is that SRC was economically most competitive against a "ORWB" crop rotation and least viable against a "MWMW" crop rotation under the given scenario conditions. This results in a significant drop in area extent and energy supply. Additional ecological synergies in the "ecological benefits" scenario came at the price of a substantial decline in suitable SRC areas. Concerning annuity differences, area extent and energy production, the production pathways of the two scenarios showed contrary results. In "income First", drying was the economically superior production pathway for SRC compared to all crop rotations, and showed a larger area extent as well as a higher energy supply for SRC compared to the "ORWB", and the "MWMW" crop rotations, and vice versa for the "ecological benefits" scenario.

Regarding the ecological effects, the influence of the production pathway was less important for both scenarios, showing no differences for erosion protection, and comparably small changes for structural 


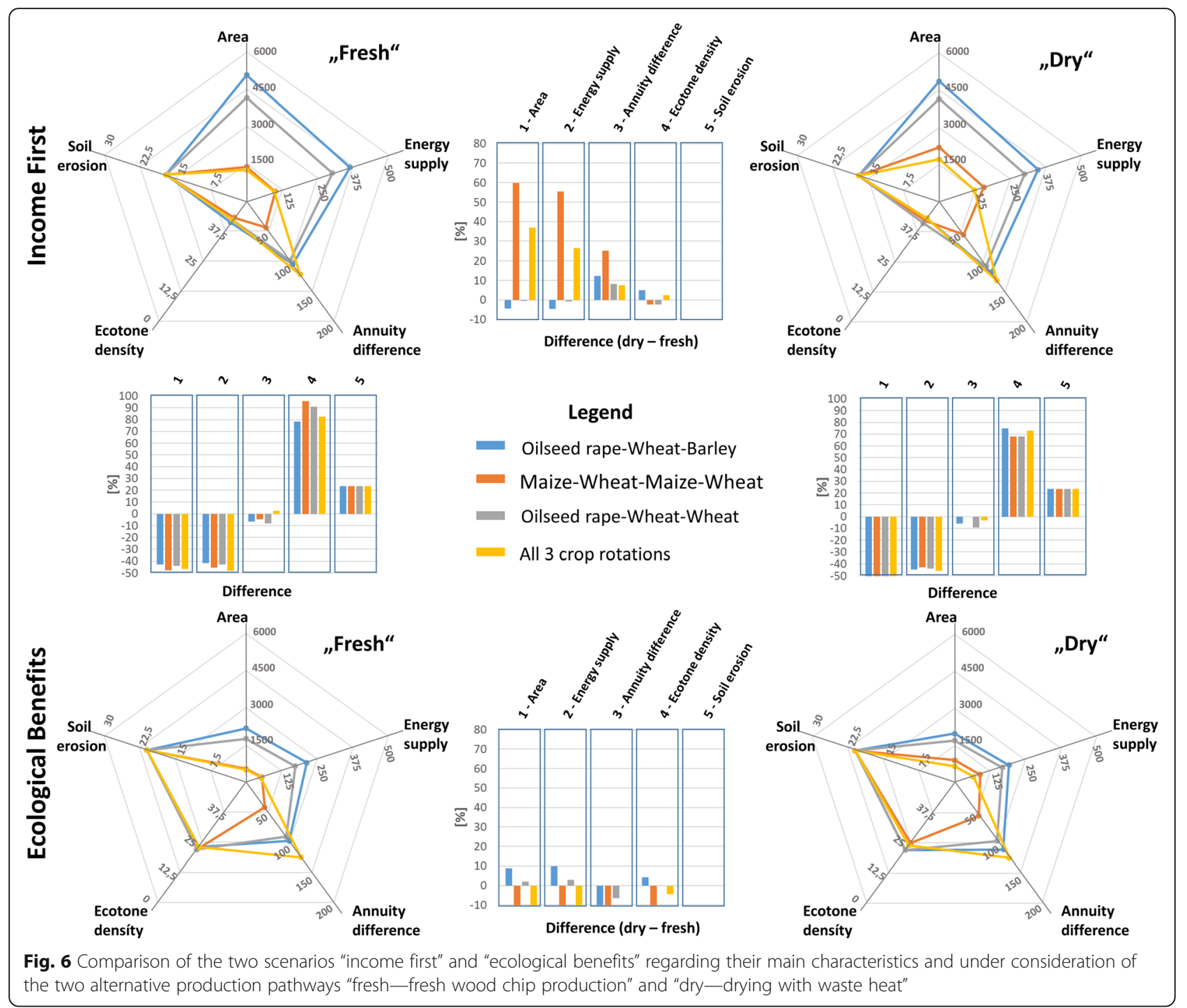

enrichment-but with opposite effects on SRC compared to a "MWMW" crop rotation and to all three crop rotations.

\section{Area and energy supply}

The extent of suitable "D1" SRC parcels in the study area ranged between a minimum of 668 ha for the "ecological benefits" scenario (compared to all three crop rotations and the fresh wood chip production pathway) and a maximum of 5074 ha for the "income first" scenario (compared to a "ORWB" rotation and fresh wood chip production pathway). This corresponds to a share between 2 and $14 \%$ of the arable area outside the priority regions for "WWSB" crop rotations (37,020 ha). Accordingly, the potential energy supply varied between a minimum of 55 and $367 \mathrm{GWh} \mathrm{a}{ }^{-1}$ which is equivalent to $7-46 \%$ of the projected renewable energy supply of the moderate scenario in the integrated climate protection plan [41]. The diminished suitable SRC areas under the "ecological benefits" scenario conditions (decline of 40-50\% compared to the "income first" scenario) resulted from the strict ecological constraints applied during the multi-criteria assessment (Fig. 6).

\section{Annuity differences}

Average annuity differences strongly differed between the crop rotations with a minimum of $42 € \mathrm{ha}^{-1} \mathrm{a}^{-1}$ for the "MWMW" crop rotation ("fresh"-"ecological benefits") and $118 € \mathrm{ha}^{-1} \mathrm{a}^{-1}$ ("dry"- "income first"). Interestingly, when compared to all three crop rotations, the average "D1 SRC annuity difference" was higher than for each single crop rotation in both scenarios and for both pathways. This can be explained by the comparably lower suitable area for the "all three crop rotations" parcel selection that induces a non-intended optimization 
"D1 SRC annuity differences". Note that the corresponding area for the fresh wood chip production pathway in the "ecological benefits" scenario is only 668 ha and for the dried wood chips pathway in the "income first" scenario restricted to 1711 ha.

\section{Ecotone density and soil erosion}

Due to the thresholds set for the environmental indicators ("Indicator evaluation" section), the "ecological benefits" scenario came with considerably higher positive effects on erosion protection and structural enrichment compared to the "income first" scenario, especially for a potential structural enrichment by SRC. Here, the positive effect was most pronounced in comparison to the "MWMW", and the "ORWW" crop rotations for the fresh wood chip production pathway. At the same time, the decline in annuity differences compared to the "income first" scenario was comparably small (3-9\%). Moreover, in case of the fresh wood chip production pathway and compared to all three crop rotations, the annuity difference even slightly inclined.

\section{Identifying synergies and trade-offs on the municipality level}

Entry point for the municipality-level analysis was the selection of the most efficient production pathway for each arable parcel where SRC is economically superior ("D1") to all three crop rotations. Based on this selection, the focus of the municipality-level analysis was on the comparison of both scenarios regarding (a) the municipal distribution of suitable SRC parcels, (b) the identification of common suitable SRC parcels and (c) the variation in annuity differences and the performance of the two production pathways.

The suitable area for the "income first" scenario comprised a district total of 1793 ha unevenly distributed over the 12 RDG municipalities (Fig. 7a) and with more than $50 \%$ of the suitable SRC parcels located in the two municipalities Gleichen (No. 9) and Staufenberg (No. 1). The primary energy supply amounted for around $130 \mathrm{GWh} \mathrm{a}^{-1}$ or $8 \%$ of the renewable energy supply in 2030 strived for by local climate protection goals. According to the amount of suitable areas and the SRC productivity, primary energy supply on a municipal level varied between 0.5 and $40 \mathrm{GWh} \mathrm{a}^{-1}$ (Fig. 7b).

For the "ecological benefits" scenario, the area of suitable SRC parcels diminished to a district total of 923 ha (Fig. 7a). Note that all these parcels are synonymous to selected parcels of the "income first" scenario implicating a $52 \%$ share of parcels with higher ecological synergies. Due to the diminished suitable area of the "ecological benefits" scenario, the total potential primary energy supply declined to $70 \mathrm{GWh} \mathrm{a}^{-1}$ (Fig. 7b).
The municipal distribution pattern of suitable SRC parcels was similar to the "income first" scenario but with some variation, e.g. the Adelebsen (No. 4) municipality having no "ecological benefits" areas, whereas the municipality of Friedland (No. 8) showed a 70\% share. Again, the municipal energy supply closely followed the area distribution with a maximum of $24 \mathrm{GWh} \mathrm{a}^{-1}$ in the municipality of Gleichen.

Concerning the wood chip production pathways, it turned out that drying with waste heat from biogas plants (Fig. 7c) was economically beneficial for 1442 ha or $81 \%$ of the area addressed by the "income first" scenario, respectively, on $84 \%$ or 775 ha of the "ecological benefits" scenario. The "municipal pattern" was quite similar for both scenarios with a variation of shares between 79 and $94 \%$ for the "income first" scenario and 74 and $97 \%$ for the "ecological benefits" scenario. The exceptional situation for the municipality of Rosdorf (No. 7)-showing fresh wood chip production as the only option, reflected the effects of the spatial selection procedure. Since the arable parcels closer to biogas plants were excluded from the analysis due to very high crop productivity (being economically superior to SRC) in this municipality, only remote parcels were part of the assessment procedure-leading to the sole selection of fresh wood chip production as a feasible pathway.

The boxplot illustration (Fig. 7d) reveals a considerable variation in median annuity differences on the municipality level. For the "income first" scenario, the median annuity difference varied between 77 and $207 €$ $\mathrm{ha}^{-1} \mathrm{a}^{-1}$ which equals a deviation between -41 and $+59 \%$ compared to the median annuity difference of $130 € \mathrm{ha}^{-1} \mathrm{a}^{-1}$ on the district level. The municipal variation of median annuity differences for the "ecological benefits" scenario showed a similar pattern and ranged between 63 and $236 € \mathrm{ha}^{-1} \mathrm{a}^{-1}$. Despite the similar municipal pattern, the median annuity differences were slightly lower in seven out of 12 municipalities compared to the "income first" scenario-leading to a diminished median annuity difference of $119 € \mathrm{ha}^{-1} \mathrm{a}^{-1}$ on the district level (Fig. 7d).

In contrast to a slightly diminished economic performance, the suitable areas of the "ecological benefits" scenario came with a considerable increase of ecological opportunities (Fig. 7e, f). Structural enrichment could be addressed effectively in 11 municipalities which was in strong contrast to the "income first" scenario. Here, the boxplots illustrate that in nine municipalities, more than $25 \%$ of the suitable SRC area s are located in arable landscapes with higher ecotone densities which could provoke conflicts with nature conservation goals as well as scenic beauty (Fig. 7e). Since soil erosion risk is a widespread phenomenon in the 

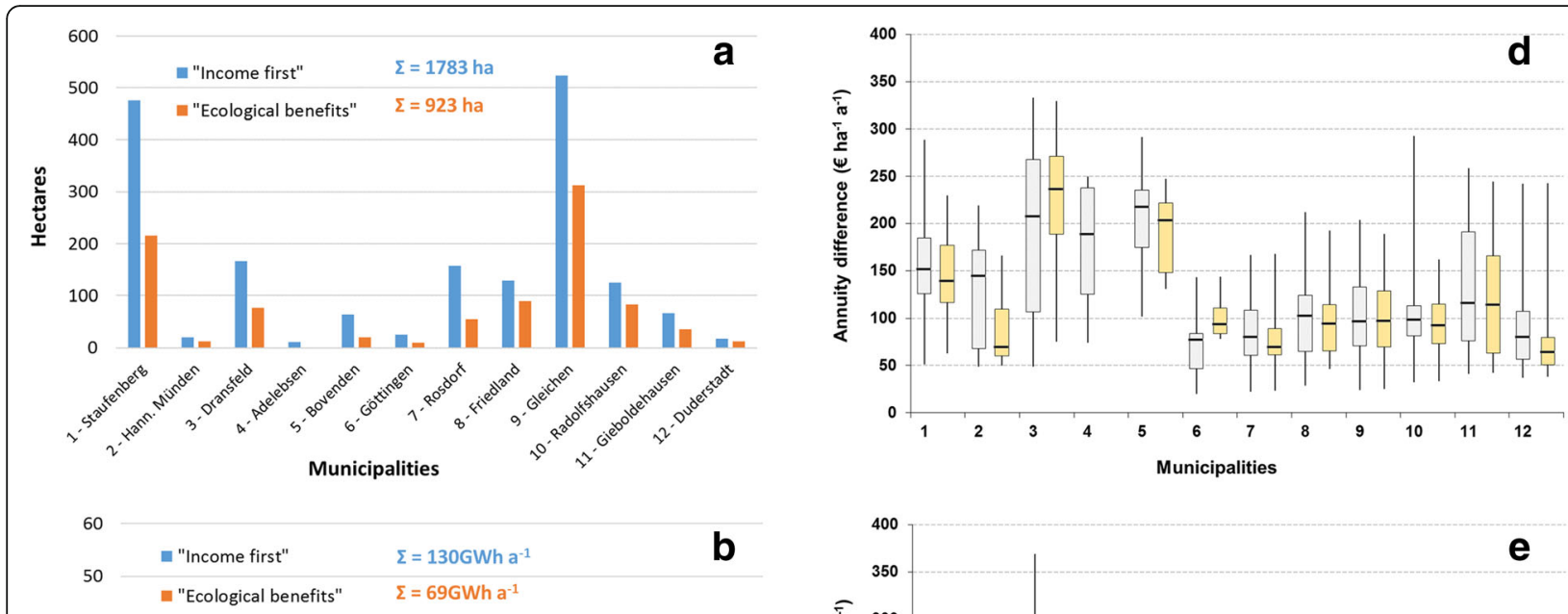

b
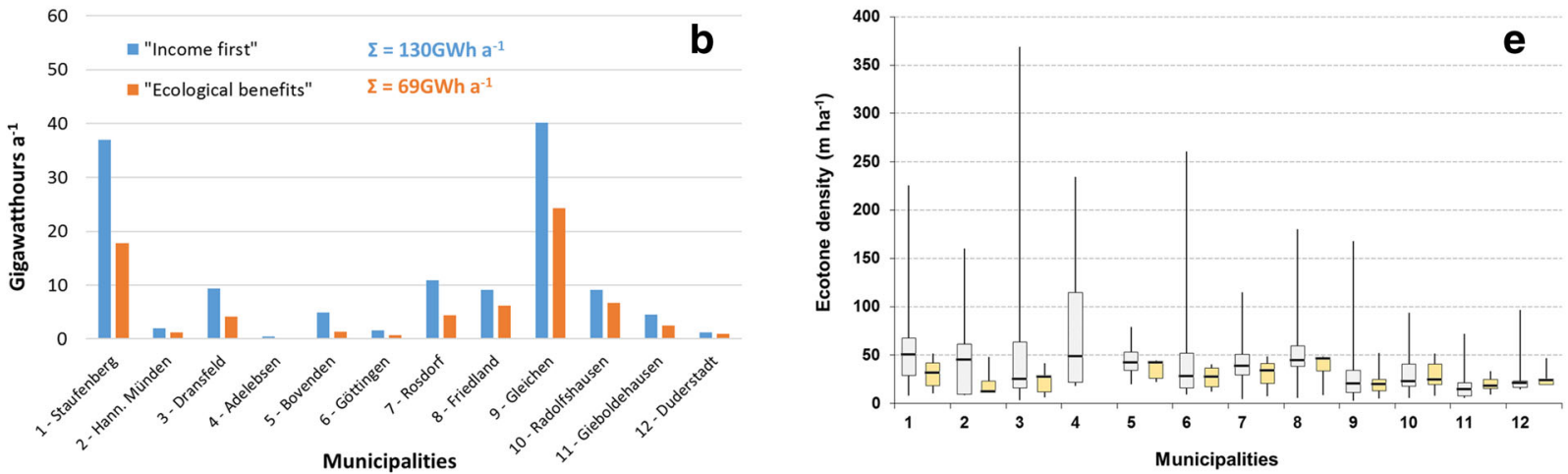

C
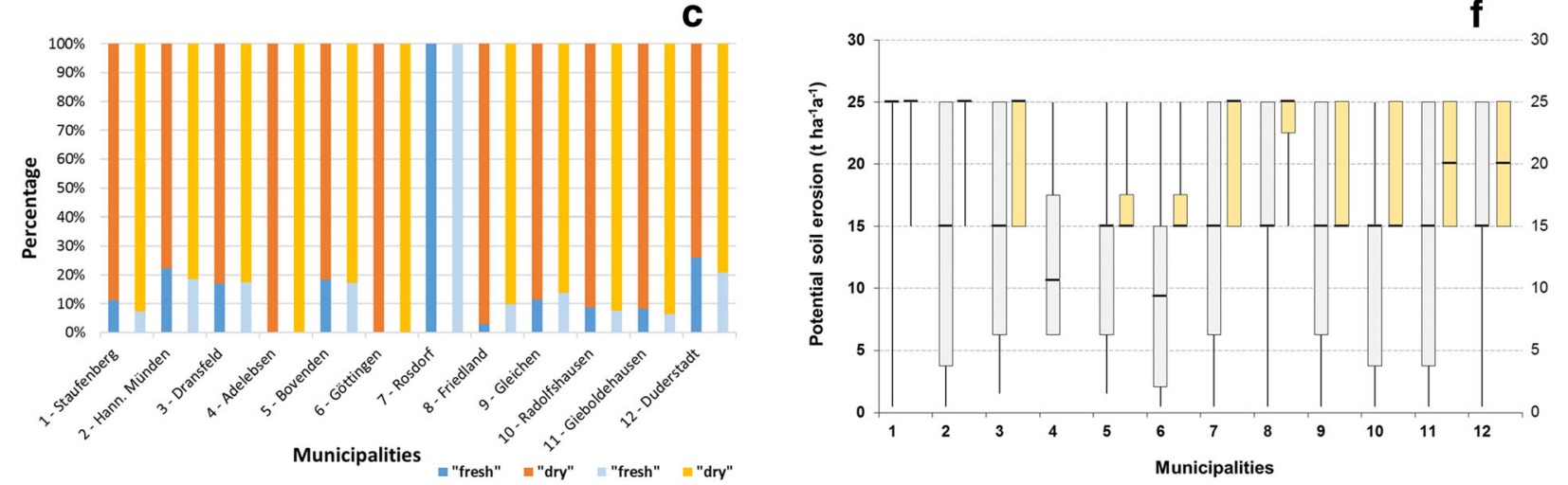

Fig. 7 Main characteristics of suitable "D1" SRC parcels against all three crop rotation for the "income first" and the "ecological benefits" scenario illustrating the following: a area extent, $\mathbf{b}$ annuity differences, c energy supply, $\mathbf{d}$ ecotone density, e excellence of production pathways expressed as percentage share of the suitable areas and $\mathbf{f}$ potential soil erosion

study area, even the suitable SRC parcels of the "income first" scenario provide ample opportunity for erosion protection (Fig. 7f). However, due to the threshold setting as part of the scenario quantification process ("Indicator evaluation" section), only parcels that are very exposed to soil erosion risk and require cross-compliance measures for soil protection were selected in the "ecological benefits" scenario. Figure $7 f$ illustrates this substantially increased level of soil protection on the suitable SRC parcels.

The boxplots (Fig. $7 \mathrm{~d}-\mathrm{f}$ ) further indicate that maximum synergies between ecological services and economic return are most likely to expect in the municipalities $1,3,5,9$ and 11 due to the combination of comparably high annuity differences for both scenarios and the additional gain for erosion protection and structural enrichment from the "ecological benefits" scenario.

\section{Identifying synergies and trade-offs on the parcel level}

Knowing the distribution of suitable areas, their level of annuity differences and the share of parcels where multiple scenario objectives are met is a valuable information provided by the district- and municipality-level analysis. The specific evaluation of synergies and tradeoffs, however, has to take place on the parcel level. 
Thus, leaning on the participatory scenario generation in the study area, a potential stakeholder dialogue between farmers, nature conservationists and regional planners was mimicked to select the most suitable SRC parcels according to the following four objectives: (a) SRC suitability is assessed against all three crop rotations and the most efficient production pathway, (b) parcels with the highest annuity difference from the "income first" scenario are selected, (c) parcels with the highest average score from the "ecological benefits" scenario are selected and (d) parcels with the maximum score of one criterion from the "ecological benefits" scenario are selected.

This way, specifics of a potential win-win situation between economic return and positive ecological effects as well as potential trade-offs can be visualized and discussed. For the cartographic illustration example (Fig. 8), the selected area of the most suitable SRC parcels was restricted to 12 ha each.

As suggested by Fig. 7 in the previous section, the most suitable parcels are located in the municipality of Dransfeld (No. 3). In total, 23 parcels were identified regarding the four objectives with eight parcels being suitable for more than one objective (see Fig. 8). However, only two parcels of the "income first" selection met all four objectives representing a win-win situation by combining high annuity differences with a great potential of environmental benefits from planting SRC. When aiming at increasing the environmental synergies, the other four parcels of the "income first" selection need to be replaced by the six, respectively, the nine parcels from the "Environmental benefits" selections.

In terms of the average score selection (objective c), this would imply highest benefits for erosion protection and structural enrichment but at the cost of declining annuity differences by $65 € \mathrm{ha}^{-1} \mathrm{a}^{-1}$.

Choosing the parcels of the maximum-score alternative of the "ecological benefits" scenario (objective d) generated an equal benefit for erosion protection but lower benefits for structural enrichment. However, annuity differences only diminished by $40 € \mathrm{ha}^{-1} \mathrm{a}^{-1}$ for the six parcels needed to replace the ones from the "income first" scenario.

In terms of energy provision, a replacement of the "income first" parcel selection by the maximum-score selection would diminish the supply by $120 \mathrm{MWh} \mathrm{a}^{-1}$ or $14 \%$ which results from the comparable low SRC productivity on four out of seven parcels. Interestingly, the lower SRC productivity of the maximum-score selection did not affect the "D1" characteristics of the annuity differences because maize productivity on these parcels is particularly low too.

Apart from this parcel-to-parcel analysis, the scenario results could be used to analyse the options of ecological services in a landscape context. As one example, suitable SRC sites could provide first step stones to establish networks of woody structures as illustrated by the corridors in Fig. 8. These exemplary corridors in turn could be digitized and used as additional spatial filter rule for a new scenario generation in BEAST or the underlying database could be retrieved, e.g. to find out what payments are needed to compensate farmers on targeted parcels that are economically not competitive to the reference crop rotations.

\section{Discussion}

\section{Scenario generation and quantification}

Woody biomass cropping on agricultural land is a complex issue since it tackles various aspects ranging from technical and economic aspects over ecosystem services and nature conservation goals to policy impacts on different spatial and institutional levels. Consequently, a broad group of stakeholders is involved when it comes to local or regional decision-making processes. A participative scenario generation process supported by interactive visualization tools provides an effective methodology to interlink these objectives by facilitating the complex negotiation process between various stakeholder groups and local key players. Applying the scenario generation and quantification approach with the BEAST framework allows to "trace-back the results" and to rapidly modify the scenario setting-starting from the input information over the criteria evaluation to the setting of spatial filter rules and the selection of the multicriteria evaluation procedure (see Fig. 9). The scenario quantification methodology presented in this contribution reflects the BEAST approach $[29,44,100]$ and could be used as a blueprint for other regions independent of the goals or the spatial configuration. This is because the BEAST approach just provides a shell where, e.g. the type of indicators, the reference crops or the spatial filter rules could be exchanged according to the specific targets of the application. Database and geometry export allows for further spreadsheet or GIS analysis. GIS-postprocessing results can be imported to BEAST and enhance the analysis options considerably. This way, an iterative scenario development can be supported and different kinds of production or value chains can be analysed. Currently, the International Energy Agency is preparing a report on BEAST to support the application of this methodology in the international context [100].

Based on the experience of several SRC projects (NOVALIS, Rating-SRC, BEST [23, 24, 29], the presented approach is deemed as a flexible interactive support to facilitate local dialogues as part of a multi-step stakeholder involvement. Beginning with a broader dialogue and participatory scenario generation with tools like BEAST, it is appropriate to proceed in smaller 


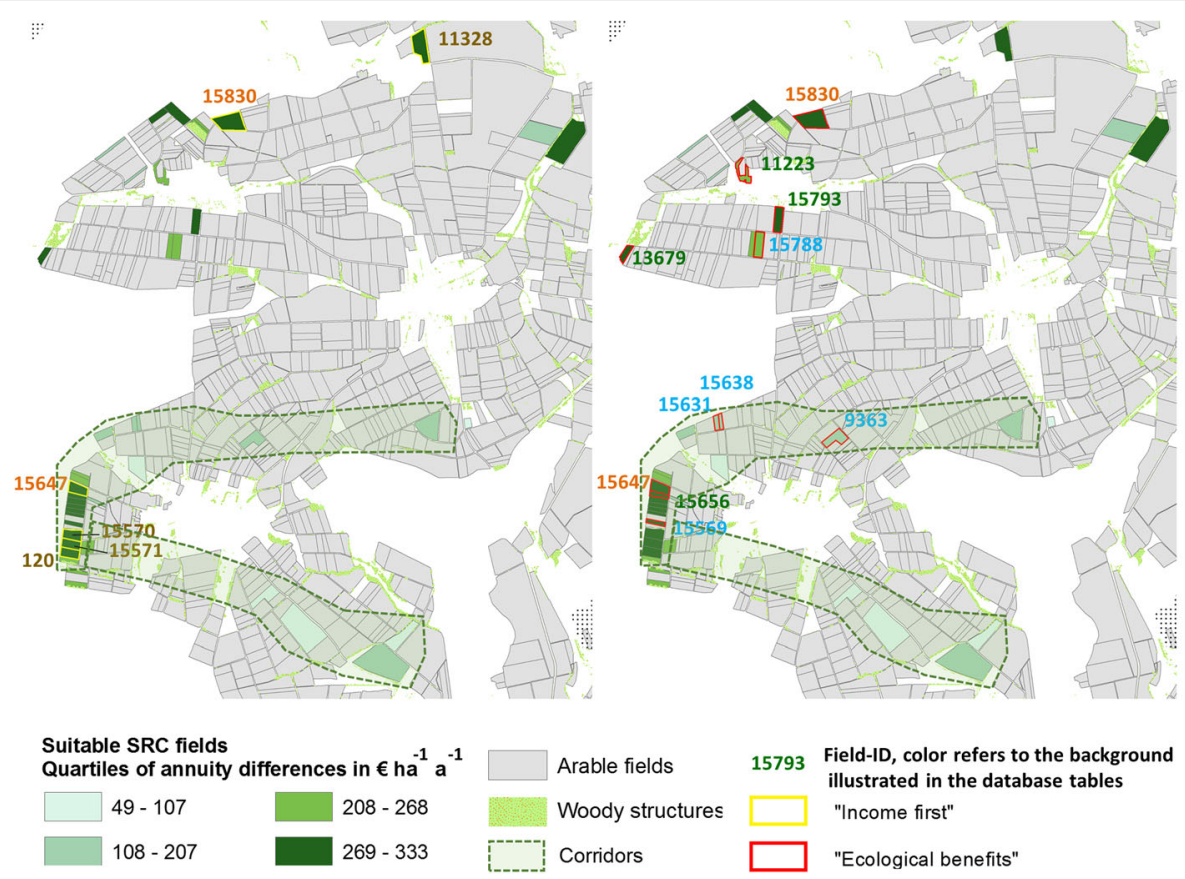

"Income first"

\begin{tabular}{|c|c|c|c|c|c|c|c|c|c|c|}
\hline Field-ID & Energy & AREA & Erosion & ED & $A D$ & w & $B$ & OR & M & SRC \\
\hline & $\left(M W h a^{-1}\right)$ & ha & $€ h a^{-1} a^{-1}$ & $m \mathrm{ha}^{-1}$ & $\epsilon h \mathrm{a}^{-1} \mathrm{a}^{-1}$ & $d t h a^{-1} a^{-1}$ & $d t h a^{-1} a^{-1}$ & $d t h a^{-1} a^{-1}$ & $d t h a^{-1} a^{-1}$ & $t_{\text {od }} h^{-1} a^{-1}$ \\
\hline 120 & 130 & 1,3 & 4 & 24,8 & 333 & 72 & 70 & 39 & 201 & 20 \\
\hline 15830 & 195 & 3,3 & 25 & 14,7 & 329 & 82 & 73 & 39 & 145 & 12 \\
\hline 11328 & 127 & 2,8 & 2 & 32,4 & 320 & 84 & 79 & 40 & 132 & 13 \\
\hline 15647 & 143 & 1,5 & 25 & 24,8 & 312 & 74 & 70 & 40 & 199 & 20 \\
\hline 15570 & 140 & 1,4 & 4 & 24,8 & 308 & 72 & 67 & 38 & 201 & 20 \\
\hline 15571 & 127 & 1,3 & 4 & 24,8 & 297 & 72 & 68 & 38 & 201 & 20 \\
\hline Sum/Avg & 862 & 12 & 10 & 24 & 317 & 76 & 71 & 39 & 180 & 17 \\
\hline
\end{tabular}

“Ecological benefits" - Maximum criterion value selection

\begin{tabular}{|c|c|c|c|c|c|c|c|c|c|c|}
\hline Field-ID & MWh a-1 & AREA & Erosion & ED & $A D$ & W & B & OR & M & SRC \\
\hline & $\left(M W h \mathrm{a}^{-1}\right)$ & ha & $€ h a^{-1} a^{-1}$ & $\mathrm{~m} \mathrm{ha}^{-1}$ & $€ \mathrm{ha}^{-1} \mathrm{a}^{-1}$ & dt ha $a^{-1} a^{-1}$ & dt ha $a^{-1} a^{-1}$ & dt ha ${ }^{-1} a^{-1}$ & dt ha $a^{-1} a^{-1}$ & $t_{o d} h a^{-1} a^{-1}$ \\
\hline 15793 & 86 & 1,6 & 25 & 3,6 & 285 & 84 & 71 & 40 & 137 & 11 \\
\hline 11223 & 52 & 1,1 & 15 & 3,6 & 248 & 74 & 70 & 40 & 158 & 10 \\
\hline 15647 & 143 & 1,5 & 25 & 24,8 & 312 & 74 & 70 & 40 & 199 & 20 \\
\hline 15656 & 61 & 0,6 & 25 & 24,8 & 286 & 74 & 70 & 40 & 198 & 20 \\
\hline 15830 & 195 & 3,3 & 25 & 14,7 & 329 & 82 & 73 & 39 & 145 & 12 \\
\hline 9363 & 129 & 2,9 & 25 & 26,0 & 207 & 83 & 75 & 41 & 110 & 10 \\
\hline 13679 & 76 & 0,8 & 25 & 12,6 & 270 & 73 & 68 & 38 & 214 & 19 \\
\hline Sum/Avg. & 742 & 12 & 24 & 16 & 277 & 78 & 71 & 40 & 166 & 14 \\
\hline
\end{tabular}

"Ecological benefits" - Average criteria value selection

\begin{tabular}{|c|c|c|c|c|c|c|c|c|c|c|}
\hline Field-ID & MWh a-1 & AREA & Erosion & ED & $\overline{A D}$ & $\mathbf{w}$ & B & OR & M & SRC \\
\hline & $\left(M W h a^{-1}\right)$ & ha & $€ h \mathbf{a}^{-1} a^{-1}$ & $m \mathrm{ha}^{-1}$ & $€ h a^{-1} a^{-1}$ & dt $h a^{-1} a^{-1}$ & $d t h a^{-1} a^{-1}$ & dt ha $a^{-1} a^{-1}$ & dt ha ${ }^{-1} a^{-1}$ & $t_{\text {od }} h a^{-1} a^{-1}$ \\
\hline 15793 & 86 & 1,6 & 25 & 4 & 285 & 82 & 71 & 40 & 137 & 11 \\
\hline 15830 & 195 & 3,3 & 25 & 15 & 329 & 82 & 73 & 39 & 145 & 12 \\
\hline 15631 & 51 & 0,6 & 25 & 9 & 191 & 74 & 72 & 40 & 211 & 18 \\
\hline 15788 & 103 & 1,6 & 15 & 4 & 247 & 80 & 76 & 40 & 145 & 13 \\
\hline 15638 & 38 & 0,4 & 25 & 9 & 184 & 74 & 72 & 39 & 211 & 18 \\
\hline 11223 & 52 & 1,1 & 15 & 4 & 248 & 74 & 70 & 40 & 158 & 10 \\
\hline 13679 & 76 & 0,8 & 25 & 13 & 270 & 73 & 68 & 38 & 214 & 19 \\
\hline 15647 & 143 & 1,5 & 25 & 25 & 312 & 74 & 70 & 40 & 199 & 20 \\
\hline 15656 & 61 & 0,6 & 25 & 25 & 286 & 74 & 70 & 40 & 198 & 20 \\
\hline 15569 & 55 & 0,6 & 25 & 25 & 280 & 73 & 70 & 39 & 200 & 20 \\
\hline Sum/Avg. & 861 & 12 & 23 & 13 & 263 & 76 & 71 & 39 & 182 & 16 \\
\hline
\end{tabular}

Fig. 8 Location of the most suitable SRC parcels according to the score calculation for the "income first" scenario and the two alternatives for the "ecological benefits" scenario. The different colours of the database rows illustrate which parcels belong to multiple selections: brown - "income first" only, orange - "income first" and "ecological benefits", green — both alternatives of the "ecological benefits" selection, blue —only one alternative of the "ecological benefits" scenario. Abbreviations: $E D$ ecotone density, $A D$ annuity difference, $W$ wheat, $B$ barley, $O R$ oilseed rape, $M$ maize 


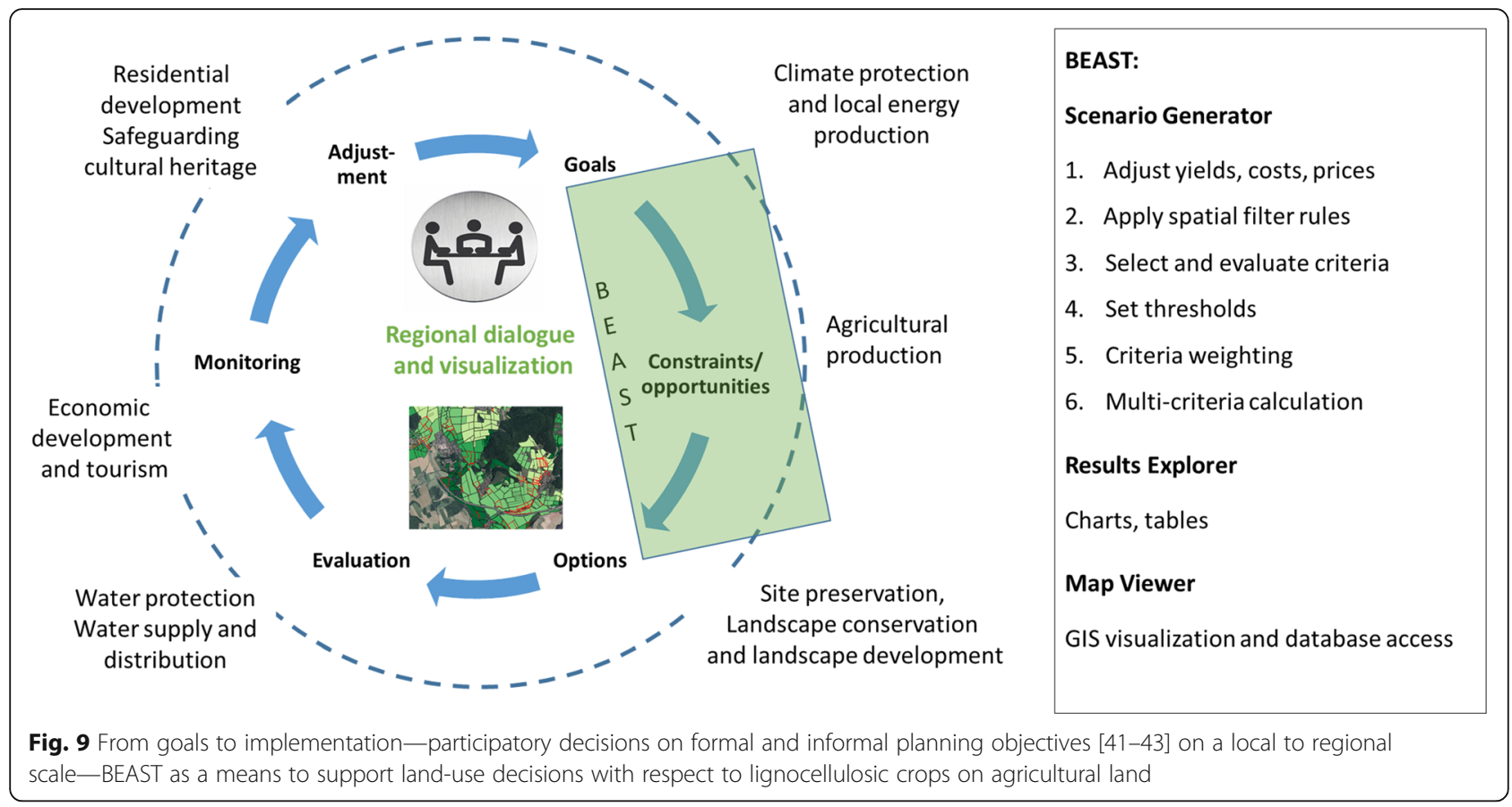

expert groups and to apply more complex (but less transparent) approaches, e.g. to address monitoring and evaluation aspects (Fig. 9), on various spatial and temporal scales. Here, dynamic modelling with cellular automata approaches and multi-objective decisionmaking (MODM) are effective methods. Existing tools like GISCAME [114] or LUMASS [115] provide possible solutions. For multi-criteria farm-level assessments, a linkage between econometric farm-models like EÖM-Monica as part of the LANDCARE-DSS [116] with scenario and evaluation tools like BEAST or MANUELA [117] and yield-models like BIOSTAR [118] or EÖM-Yieldstat [116] are viable options.

As illustrated by Fig. 9, there are several typical local goals in place, many of them directly or indirectly addressed by woody biomass cropping. The scenario results of this study addressed a couple of these goals by showing the amount of potential biomass supply, identifying parcels with the potential to diversify farmers' income and illustrating opportunities to generate ecological synergies. The identification of optimal parcel locations for SRC follows the "multi-attribute decisionmaking" (MADM) methodology [119], and allows to combine multiple goals with multiple criteria. However, it is not possible to address optimal solutions for multiple objectives in a spatial context. This would require mathematical optimization algorithms, e.g. in form of linear programming [120] which in turn makes it much more difficult to understand the relation between scenario settings and optimization results. Again, these aspects should be subject to further, more expertoriented workshops and adapted model applications.

\section{Annuities}

Annuities were calculated under consideration of price fluctuations but deliberately not with annual price and cost changes since the major focus was on relating the study results with current levels of annuities, respectively, their differences. Moreover, not including annual price and cost changes is considered as a conservative calculation for two major reasons: (a) In the last decade (2006-2015), wood chip prices increased at a higher rate and with lower price fluctuations than annual crop commodities [68-71], and (b) given an extension of SRC area, it is likely that future cost increases for SRC will be lower than for annual crops because there is plenty of room for improving efficiency (see Fig. 10), regarding e.g. logistics, availability of machinery or harvesting technology.

\section{Yield calculation}

Yield levels as one important input for the economic assessment were simulated as average decadal yields with statistical yield models for the annual reference crops and with a combined empirical-statistical approach for SRC [this study, 26]. Yield fluctuations were stochastically addressed via Monte Carlo simulation runs. This approach was deemed as being best adapted to the goals of the scenario generation process and which were to assess opportunities and constraints 




Fig. 10 Cost variation of SRC cost positions based on a literature review of 32 sources on German SRC plantations [65-67, 72-99]

of SRC over a 20-year time period with respect to existing local goals. However, for further studies it would be interesting to compare spatial patterns caused by the current modelling approach with results calculated, e.g. with BIOSTAR [118].

Due to the very limited available data on long-term SRC yields, the analysis was restricted to poplar as reference species. Here, the MAX-1 clone in the 5-year rotation was taken as reference because this combination represents a common clone with an economically efficient rotation period.

\section{Risk evaluation via the concept of stochastic dominance}

Results of this study indicate that a thorough parcel selection is crucial to gain economic return from SRC which is competitive to common arable crop rotations on a low risk-level. A low risk-level that addresses riskaverse farmers, as the majority of the German farmers [102], was determined as a stochastic first-order dominant positive annuity difference from SRC compared to the annual reference rotations. Wolbert-Haverkamp and Mußhoff [121] introduced the real option approach (ROA) as alternative to the net present value (NPV) calculation as classical investment theory (used in this study). In contrast to the NPV approach, the ROA takes effects like the loss of flexibility or the uncertainty of investment returns into account via stochastic modelling. According to Wolbert-Haverkamp and Mußhoff, German farmers need an additional trigger of $270-342 €$ $\mathrm{ha}^{-1} \mathrm{a}^{-1}$ to opt for SRC instead of annual cropping. Transferred to this study this would imply that the suitable "D1" SRC parcels have to show an average annuity difference (i.e. the 0.5 percentile of the $\mathrm{MC}$ simulation results) that falls in this ROA range. Referring to the 1800 ha which was identified as suitable "D1" SRC areas against all three crop rotations, the average annuity difference is $295 € \mathrm{ha}^{-1} \mathrm{a}^{-1}$ and ranges between 235 and $348 € \mathrm{ha}^{-1} \mathrm{a}^{-1}$ on the municipality level. In total, around $75 \%$ of the "D1" SRC parcels meet the ROA trigger value range calculated by Wolbert-Haverkamp and Mußhoff.

Apart from a thorough site selection as riskminimizing strategy, business co-operations in SRCbased supply chains are an option to reduce risks for farmers by sharing knowledge with partners, establishing guaranteed biomass sales or limiting financial risks by sharing initial investments [27]. Especially in regions with comparable small farm sizes-as is the case for the study area-these co-operations are needed to enable joint efforts of many farmers, allowing them to contribute with only a small proportion of their arable land. In addition to private investors institutional support is an urgent need. Starting with a considerable reduction of approval and planning times, institutional actors could actively support SRC value chains by supplying selected public building with wood chips heating.

\section{Farm-level assessments}

Although the high spatial resolution allows to analyse the study results on a parcel-scale, it was not possible to carry out farm-level based assessments since information on lease contracts and land tenure were not available. For further studies, a farm-level assessment 
would allow to compare opportunities and constraints associated with farm-size and farm structure. With the consideration of lease contracts and farm-parcel distances, the current economic calculation could be varied and the effects on suitability scores could be examined.

\section{Ecological synergies and spatial patterns}

In this study, two ecological effects were exemplary assessed in combination with an economic evaluation to demonstrate the opportunities and constraints of synergies as a starting point for further elaboration in other studies. To avoid adverse effects between erosion protection and landscape structure, spatial filter rules as well as indicator thresholds were applied. The combination of spatial filter rules and indicator thresholds is a flexible tool-set to steer the spatial allocation of SRC. It is however not possible in the current scenario application with BEAST to combine indicators interactively or to quantify adverse effects between the ecological criteria. This would require a dynamic spatial and temporal assessment which would be available when supplementing BEAST with modelling approaches like GISCAME or LUMASS. In this respect, Frank et al. [114, 122, 123] for example gave interesting illustrations of how to interlink landscape metrics with the ecosystem services approach using GISCAME for the spatial simulation.

Apart from erosion protection and structural enrichment, additional SRC-related ecological effects such as water retention, ground water protection or habitat provision (e.g. [19, 22-24, 37, 51] for an overview) should be taken into account. Here, BEAST provides a flexible shell to exchange or add indicators.

\section{Conclusions}

Landscape transformation due to the expansion of renewable energies has become an issue during the last two decades and needs local/regional concepts to steer land-use decisions more pro-actively. Participatory scenario generation and visualization of results can help local actors to identify common interests, reduce perception barriers and start off e.g. with cooperations between farmers, local institutions and business partners.

Concerning the stakeholder involvement, a multistep approach seems to be appropriate to combine formal and informal planning goals as well as add a dynamic (e.g. monitoring) component to existing planning processes. Beginning with a broader dialogue and participatory scenario generation with tools like BEAST, the elaboration of these findings as well as the dynamic spatial-temporal analysis needs more complex modelling approaches and should then be subject to smaller expert groups. Both steps need a small series of workshops and then follow-ups (e.g. biannual) with a targeted and iterating identification of synergies between economic return and ecological services to monitor and evaluate the process.

Short rotation coppice is an economic viable alternative for renewable energy production in the case study region with the strength to provide, respectively, to protect selected ecosystems services which are different to annual crops or which annual crops are lacking. SRC could be particularly valuable when bridging distinct land cover types and mediating between different land-use intensities in agricultural landscape. The suitable areas identified in this study offer a considerable potential to diversify farmers' income, provide additional renewable energy supply and create ecological synergies. The spatial explicit visualization allows to identify target areas for project or planning purposes with e.g. initializing potential partnerships of farmers to provide suitable parcels for SRC cropping.

However, since at least $80 \%$ of the arable parcels in the case study area are not suitable to grow SRC as a low-risk alternative to the reference crop rotations, it is of crucial importance for farmers to thoroughly select the appropriate sites and to consider the production- and marketing options. Concerning local production and marketing options, it needs a joint effort of local actors to initiate demonstration projects illustrating if and how regional supply chains could work out.

Farmers need reliable mid-term strategic partnerships to opt for SRC because they face a loss of flexibility by planting perennial crops, they have to cope with high initial investment costs and a delay of several years before the SRC system creates an economic return. Thus, contracting with annual payment schemes to bridge the income gap and/or support for initial investments needs to be a part of local implementation strategies. On the district level, in turn, these co-operations could help to interlink regional development schemes with spatial planning and climate protection goals. A first opportunity for the case study region is the further application of BEAST within the regional LEADER process in the next 2 years. To illustrate the impact of specific cost positions on the annual economic return (annuities), a set of eight variables for SRC (Table 5 in Appendix) and a set of seven variables for annual crops (Table 6 in Appendix) were varied. For SRC, "preparation and planting", "harvesting and chipping", "re-conversion", "transportation", "yieldlevel" and "price-level" were altered by $10 \%$ in relation to the 2015 reference values (see Table 5 in Appendix). 


\section{Appendix}

Table 5 Impact of cost variations on SRC annuities from SRC production with (a) no drying but reduced commodity prices of 93€ $t_{\text {od }}(80 \%$ - according to [98]), (b) drying with waste energy from biogas plants - 10\% biomass loss according to [70]

\begin{tabular}{|c|c|c|c|}
\hline \multirow[b]{3}{*}{ Cost position } & \multirow[b]{3}{*}{ Reference value } & \multicolumn{2}{|c|}{ Annuities in $€$ ha $^{-1}$ of SRC production variants } \\
\hline & & $408(93)$ & $421(116)$ \\
\hline & & Fresh wood chips [a] & Dried wood chips [b] \\
\hline Preparation and planting & $2107 €$ & \pm 15 & \pm 15 \\
\hline Harvesting and chipping & $880 €\left(16 € \mathrm{t}_{\mathrm{od}}^{-1}\right)$ & \pm 15 & \pm 15 \\
\hline Re-conversion (incl. fertilizer application) & $1900 €(1600+300)$ & \pm 7 & \pm 7 \\
\hline Transportation (20 km) & $725 €\left(14 € t_{\mathrm{od}}^{-1}\right)$ & \pm 14 & \pm 14 \\
\hline Transportation to biogas plant (5 km) & $\begin{array}{l}357.5 € \\
6.5 €\end{array}$ & - & \pm 6 \\
\hline Drying costs & $385 €\left(7 € t_{\circ d}^{-1}\right)$ & - & \\
\hline Yield-level ( $\pm 10 \%)$ & $55 t_{\text {od }} \operatorname{rot}^{-1}$ & \pm 70 & \pm 72 \\
\hline Price-level $( \pm 10 \%)$ & $93 t_{\text {od }}^{-1} / 116 t_{\text {od }}^{-1}$ & \pm 92 & \pm 104 \\
\hline Area (1 ha) & 5 ha & \pm 25 & \pm 25 \\
\hline Slope (10\%) & $0 \%$ & \pm 11 & \pm 11 \\
\hline
\end{tabular}

Table 6 Impact of cost variations on annuities from annual crop production with reference yield levels for wheat $81.2 \mathrm{dt} \mathrm{ha}^{-1} \mathrm{a}^{-1}$,

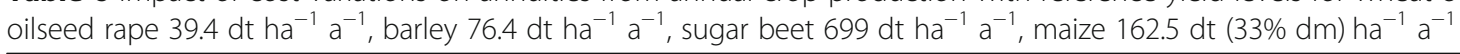

\begin{tabular}{|c|c|c|c|c|c|}
\hline \multirow[b]{3}{*}{ Cost position } & \multicolumn{5}{|c|}{ Annuity in $€$ ha $^{-1}$ and commodity prices (2006-2015 average) in $€ \mathrm{dt}^{-1}$} \\
\hline & Wheat & Oilseed rape & Barley & Sugar beet & Maize \\
\hline & $637(18.8)$ & $558(37.8)$ & $490(16.9)$ & $1406(3.96)$ & $535(10.08)$ \\
\hline Seed, fertilizer, plant protection & \pm 53 & \pm 78 & \pm 57 & \pm 89 & \pm 43 \\
\hline \multicolumn{6}{|l|}{ Depreciation on machinery } \\
\hline \multicolumn{6}{|l|}{ Transportation } \\
\hline \multicolumn{6}{|l|}{ Storage } \\
\hline \multicolumn{6}{|l|}{ Drying } \\
\hline Weed control, seedbed cultivation, cropping & \pm 21 & \pm 26 & \pm 21 & \pm 49 & \pm 33 \\
\hline Yield level $( \pm 10 \%)$ & \pm 138 & \pm 160 & \pm 126 & \pm 279 & \pm 129 \\
\hline Price-level ( $\pm 10 \%)$ & \pm 189 & \pm 179 & \pm 158 & \pm 336 & \pm 180 \\
\hline Yield increase $( \pm 15 \%)$ & \pm 30 & \pm 30 & \pm 26 & \pm 53 & \pm 5 \\
\hline Area (1 ha) & \pm 43 & \pm 44 & \pm 39 & \pm 98 & \pm 76 \\
\hline Slope (10\%) & \pm 19 & \pm 20 & \pm 17 & \pm 42 & \pm 32 \\
\hline
\end{tabular}


SRC annuities were calculated for two production pathways: (a) fresh wood chip production and sale within a $20-\mathrm{km}$ radius with a price of $93 € t_{\mathrm{od}}^{-1}$, reflecting the lower price paid for fresh material delivery [98] and (b) dried wood chip production and sale within a $20-\mathrm{km}$ radius with a price of $116 € t_{\mathrm{od}}^{-1}$ (2006-2015 average). The transportation to the closest biogas plant was calculated for a transport distance of $5 \mathrm{~km}$.

The cost-impact on annuities of diminishing "field size" was exemplary calculated for a 1-ha field and compared to the reference size of 5 ha. The impact of "slope" on costs was derived by increasing the field slope from $0 \%$ (reference) to $10 \%$.

Sensitivity analysis for annual crops was carried out in the same way as described for SRC. Additionally, yield incline due to breeding progress was included with an annual increase that reflects the long-term trend of each crop see Table 4 in the manuscript. Table 6 in Appendix indicates the dominating effect of yield increase followed by price and yield changes.

As stated for SRC, the changes in prices and yields have a substantial impact on economic return of annual crops. The relative impact is even more pronounced for annual crops.

The interest rate for the annuity calculation was set to $3.5 \% \mathrm{a}^{-1}$ for the annual reference crops as well as for SRC.

\section{Acknowledgements}

Parts of the work presented in this study were funded by the German Federal Ministry of Education and Research (BMBF), grant number 033L033A, and were developed within the BEST-Research Framework (http://best-forschung.uni-goettingen.de). I gratefully acknowledge this support.

The work of three anonymous reviewers helped to improve the manuscript and is very much appreciated.

\section{Author's information \\ GB (BALSA) is a geographer and has been working in national and international research projects since 1995. As a senior scientific research consultant and project manager, he is an expert in landscape ecology, GIS modelling and scenario -based decision support. In 2003, GB founded the Bureau for Applied Landscape Ecology and Scenario Analysis (BALSA). A focus of BALSA is on GIS modelling, land-use change assessment and on scenario development. For the last 10 years, landscape-related ecological evaluation of short rotation coppice and supporting participatory decision processes have been major topics of BALSA within multi-disciplinary research projects. GB is an exter- nal lecturer at the Georg-August-University Göttingen and associated member of the International Energy Agency (Task43).}

\section{Competing interests}

The author declares that he has no competing interests.

Received: 11 August 2015 Accepted: 6 January 2017

Published online: 31 January 2017

\section{References}

1. EU (2009) Richtlinie 2009/28/EG des Europäischen Parlamentes und Rates. Amtsblatt der Europäischen Union., L140/16. http://eur-lex.europa.eu/legalcontent/de/ALL/?uri=CELEX\%3A32009L0028. Accessed 20 May 2016

2. BMU-Bundesministerium für Umwelt, Naturschutz und Reaktorsicherheit (2005) The national climate protection programme 2005-summary., Berlin

3. European Council (2014) Council conclusions on the 2030 climate and energy policy framework., http://www.consilium.europa.eu/uedocs/cms_ data/docs/pressdata/en/ec/145356.pdf. Accessed 20 Jan 2016
4. BMWi - Federal Ministry for Economic Affairs and Energy (2016) Erneuerbare Energien in Zahlen. Nationale und internationale Entwicklung im Jahr 2015., https://www.erneuerbare-energien.de/EE/Redaktion/DE/ Downloads/erneuerbare-energien-in-zahlen-2015.pdf?_blob= publicationFile\&v=3. Accessed 20 Apr 2016

5. European Environment Agency (2006) How much bioenergy can Europe produce without harming the environment? European Environment Agency, Copenhagen

6. Eurostat (2015) Energy, transport and environment indicators., http://ec. europa.eu/eurostat/documents/3217494/7052812/KS-DK-15-001-EN-N.pdf/ eb9dc93d-8abe-4049-a901-1c7958005f5b. Accessed 22 Mar 2016

7. Dimitriou I, Rutz D (2015) Sustainable short rotation coppice. A handbook., http://www.srcplus.eu/images/Handbook_SRCplus.pdf. Accessed 11 Mar 2016

8. FNR - Agency for Renewable Resources (2016) Bioenergy in Germany: facts and figures 2015. FNR, Gülzow

9. Deutscher Bundestag (2014) Act on the development of renewable energy sources (Renewable Energy Sources Act - RES Act 2014., http://www.bmwi. de/English/Redaktion/Pdf/renewable-energy-sources-act-eeg-2014,property= pdf,bereich=bmwi2012,sprache=en,rwb=true.pdf. Accessed 14 Feb 2016

10. BUND - Bund für Umwelt- und Naturschutz (2010) Energetische Nutzung von Biomasse., http://www.bund.net/fileadmin/bundnet/publikationen/ energie/20101223_energie_position_biomasse.pdf. Accessed 05 Oct 2016

11. Peters W, Schultze C, Schümann K, Stein S (2010) Bioenergie und Naturschutz. Synergien fördern, Risiken vermeiden. BfN - Bundesamt für Naturschutz, Bonn

12. German Natinal Academy of Sciences - Leopoldina (2012) Bioenergy — chances and limits. German National Academy of Sciences Leopoldina, Halle (Saale)

13. Wissenschaftlicher Beirat Agrarpolitik (2007) Nutzung von Biomasse zur Energiegewinnung - Empfehlungen an die Politik. http://www.bmel.de/ SharedDocs/Downloads/Ministerium/Beiraete/Agrarpolitik/GutachtenWBA. pdf?_blob=publicationFile. Accessed 15 Nov 2015

14. Don A, Osborne B, Hastings A et al (2012) Land-use change to bioenergy production in Europe: implications for the greenhouse gas balance and soil carbon. Glob Change Biol Bioenergy 4:372-391. doi:10.1111/j.1757-1707. 2011.01116.x

15. Zimmer Y, Berenz S, Döhler H et al (2008) Klima- und energiepolitische Analyse von Bioenergielinien., Landbauforschung vTl Agriculture and Forestry Research 318

16. Kort J, Collins M, Ditsch D (1998) A review of soil erosion potential associated with biomass crops. Biomass Bioenergy 14:351-359

17. Scholz V, Krüger K, Höhn A (2001) Vergleichende Untersuchungen zum umweltverträglichen und energieeffizienten Anbau von Energiepflanzen. Arch Agron Soil Sci 47:333-361

18. Deumlich D, Funk R, Frielinghaus M, Schmidt W, Nitzsche O (2006) Basics of effective erosion control in German agriculture. J Plant Nutr Soil Sci 169:370-381

19. Schmidt-Walter P, Lamersdorf N (2012) Biomass production with willow and poplar short rotation coppices on sensitive areas-the impact on nitrate leaching and groundwater recharge in a drinking water catchment near Hanover, Germany. Bioenergy Res 5(3):546-562

20. Schulz U, Brauner O, Gruß H (2009) Animal diversity of short rotation coppices-a review. Landbauforsch vTi AG 59(3):171-182

21. Cunningham MD, Bishop JD, McKay HV, Sage RB (2004) ARBRE monitoring -ecology of short rotation coppice. Department of Trade and Industry, London

22. Baum S, Bolte A, Weih M (2012) High value of short rotation coppice plantations for phytodiversity in rural landscapes. Glob Change Biol Bioenergy 4:728-738. doi:10.1111/j.1757-1707.2012.01162.x

23. Busch G, Lamersdorf N (eds) (2009) Kurzumtriebsplantagen. Handlungsempfehlungen zur naturverträglichen Produktion von Energieholz in der Landwirtschaft, Ergebnisse aus dem Projekt NOVALIS [SRC on agricultural sites - recommendations for an environmentally sound production]. DBU, Osnabrück

24. Dimitriou I, Baum C, Baum S, Busch G, Schulz U, Köhn J et al (2011) Quantifying environmental effects of short rotation coppice (SRC) on biodiversity, soil and water., 2011. IEA Bioenergy Task43, Report 1:2011

25. Tsonkova P, Böhm C, Quinkenstein A, Freese D (2012) Ecological benefits provided by alley cropping systems for production of woody biomass in the temperate region: a review. Agrofor Syst 85:133-152

26. Boll T, von Haaren C, Rode M (2015) The effects of short rotation coppice on the visual landscape. In: Bemmann A, Butler Manning D et al (eds) 
Bioenergy from Dendromass for the Sustainable Development of Rural Areas. Wiley-VCH, Weinheim, pp 105-119

27. Boll T, Neubert F, Zimmerman K, Bergfeld A (2015) Decision criteria and implementation strategies for sort eotation coppice in Germany from the perspective of stakeholders. In: Bemmann A, Butler Manning D, et al. (eds) Bioenergy from Dendromass for the Sustainable Development of Rural Areas. Wiley-VCH, Weinheim, pp 331-346

28. Kröber M, Heinrich J, Wagner P (2015) The economic assessment of short rotation coppice plantations and their profitability relative to annual crops in Sachsen, Germany. In: Bemmann A, Butler Manning D et al (eds) Bioenergy from Dendromass for the Sustainable Development of Rural Areas. Wiley-VCH, Weinheim, pp 317-330

29. Busch G, Thiele JC (2015) The bioenergy allocation and scenario tool (BEAST) to assess options for the siting of short rotation coppice in agricultural landscapes: tool development and case study results from the Göttingen district. In: Bemmann A, Butler Manning D et al (eds) Bioenergy from Dendromass for the Sustainable Development of Rural Areas. WileyVCH, Weinheim, pp 23-43

30. Bredemeier M, Busch G, Hartmann L, et al. (2015) Fast growing plantations for wood production and integration of ecological effects and economic perspectives. Front Bioeng Biotechnol. doi: 10.3389/fbioe.2015.00072

31. Mantau et al (2011) Real potential for changes in growth and use of EU forests, EUwood study., http://www.egger.com/downloads/bildarchiv/187000/1 187099_DV_Real-potential-changes-growth_EN.pdf. Accessed 10 Apr 2016

32. European Commission (2014) State of play on the sustainability of solid and gaseous biomass used for electricity, heating and cooling in the EU, Commission Staff working document (259). https://ec.europa.eu/energy/ sites/ener/files/2014_biomass_state_of_play_pdf. Accessed 10 Apr 2016

33. Pelkonen et al (2014) What science can tell us: Forest Bioenergy for Europe. http://www.efi.int/files/attachments/publications/efi_wsctu_4_net.pdf. Accessed 15 Apr 2016

34. IRENA (2014) Global bioenergy supply and demand projections-A working paper for REmap 2030. https://www.irena.org/remap/IRENA_REmap_2030_ Biomass_paper_2014.pdf. Accessed 15 Apr 2016

35. Dimitriou I, Eleftheriadis I, Hinterreiter S et al (2014) Short rotation woody crops (SRC) plantations for local supply chains and heat use-best practice examples on sustainable local supply chains of SRC. WIP Renewable Energies, Munich

36. Anonymous (2015) Energy crops in Europe: best practice in SRC biomass from Germany, Ireland, Poland, Spain, Sweden \& UK. Results from the EUfunded Rokwood project: "Fuelling dialogue between biomass research, industry, policy \& business. http://www.rokwood.eu/public-library/finalpublication/send/29-final-publication/57-rokwood-final-publication.html. Accessed 15 Apr 2016

37. Bemmann A, Butler Manning D (eds) (2013) Energieholzplantagen in der Landwirtschaft. Agrimedia, Hannover

38. Bergfeld A, Michalk K (2015) Opportunities provided by formal and informal planning to promote the cultivation of dendromass for energy and the establishment of wood-based supply chains in Germany. In: Bemmann A, Butler Manning D et al (eds) Bioenergy from Dendromass for the Sustainable Development of Rural Areas. Wiley-VCH, Weinheim, pp 375-389

39. Henke S, Theuvsen L (2014) SLCA: regional differenzierte Bewertung von Biogasanlagen und Kurzumtriebsplantagen. Jahrbuch der Österreichischen Gesellschaft für Agrarökonomie, Wien, pp 81-90

40. BfN/BBR - Bundesamt für Naturschutz/Bundesinstitut für Bau-, Stadt- und Raumforschung (2014) Band 3: Energiewende als Herausforderungen für Regionen. BfN/BBR, Bonn

41. Landkreis Göttingen (2010) Regionales Raumordnungsprogramm für den Landkreis Göttingen. Landkreis Göttingen, Amt für Kreisentwicklung und Bauen, Göttingen

42. Landkreis Göttingen (2013) Landkreis Göttingen—Integriertes Klimaschutzkonzept für den Landkreis. http://www.landkreisgoettingen.de/ magazin/artikel.php?artikel=5307\&type=\&menuid=464\&topmenu=442\&ID= 8887 e6n6t0j45mb3qdheqt3qm4. Accessed 7 Nov 2014

43. LAG - Lokale Aktionsgruppe Göttinger Land (2014) Dörfer gemeinsam zukunftsfähig gestalten. Regionales Entwicklungskonzept LEADER-Region Göttinger Land Fortschreibung EU-Förderphase 2014 - 2020. LEADER Regionalmanagement, Göttingen

44. Thiele JC, Busch G (2015) A decision support system to link stakeholder perception with regional renewable energy goals for woody biomass. In:
Bemmann A, Butler Manning D (eds) Bioenergy from dendromass for the sustainable development of rural areas. Wiley- $\mathrm{VCH}$, Weinheim, pp 433-445

45. Landgraf D, Böcker L, Schildbach M, Wolf H (2010) Baumarten- und Sortenwahl. In: Skodawessely C, Pretzsch K, Bemmann A (eds.) Beratungshandbuch zu Kurzumtriebsplantagen: Entscheidungsgrundlagen zur Etablierung von Kurzumtriebsplantagen in Deutschland. TU Dresden, Dresden, pp 66-71.

46. Schuler J (2014) Instrumente zur Stärkung von Synergien zwischen Natur- und Klimaschutz im Bereich Landbewirtschaftung: Ergebnisse des F+E-Vorhabens (FKZ 351188 0200) "Stärkung von Synergien zwischen Naturschutz und Klimaschutz im Bereich Landbewirtschaftung. BfN Bundesamt für Naturschutz, Bonn-Bad Godesberg. Deutschland

47. DWD - German Weather Service (2013) Digital precipitation and temperature data on a $1 \mathrm{~km}^{2}$ grid. http://www.dwd-shop.de/index.php/ default/vergangenes-wetter-klimainfos/deutschland-allgemein/weste-alg-ep. html.Accessed 18 Nov 2014

48. LBEG - Landesamt für Bergbau, Energie und Geologie (2015) Bodenübersichtskarte von Niedersachsen, Blätter L4324, 4326,L4522, 4524, L4526, L4722, L4724. Landesamt für Bergbau, Energie und Geologie, Hannover

49. NLS - Niedersächsisches Landesamt für Statistik (2000-2015) Statistische Berichte Niedersachsen. Bodennutzung und Ernte 2002-2015 (Regional agricultural yield statistics for the years 2002-2015). NLS, Hannover

50. DGS - Deutsche Gesellschaft für Sonnenenergie e.V (2015) EEGAnlagenregister., http://www.energymap.info/download.html. Accessed 15 Feb 2016

51. Wilhelm E-G, Nych F, Schmidt PA, Winter S (2015) Synergies and conflicts between an increasingly widespread cultivation of short rotation coppice and nature conservation at the landscape level. In: Bioenergy from Dendromass for the Sustainable Development of Rural Areas. Wiley- $\mathrm{VCH}$, Weinheim, pp 79-96

52. Jennemann L, Peters W, Rosenthal S, Schöne F (2011) Naturschutzfachliche Anforderungen für Kurzumtriebsplantagen. Praktische Umsetzung von Maßnahmen bei der Neuanlage und Bewirtschaftung von Energieholzflächen (Voruntersuchung). NABU-Bundesverband und Bosch \& Partner GmbH, Berlin. https://www.bfn.de/fileadmin/MDB/documents/ themen/erneuerbareenergien/Publikationen_EuE/kup-anforderungen.pdf. Accessed 20 Apr 2015

53. LSN - Landesamt für Statistik Niedersachsen (2015) Erntestatistik online. http://www.nls.niedersachsen.de/Tabellen/Landwirtschaft/ernte03/ernte03. htm. Accessed 20 Nov 2015

54. LSKN - Landesbetrieb für Statistik und, Kommunikationstechnologie (2012) Statistische Berichte Niedersachsen. Bodennutzung, Reihe A: Gemeindeergebnisse. Landesbetrieb für Statistik und Kommunikationstechnologie Niedersachsen, Hannover

55. von Behr W, Bemmann A, Michalk K et al (2012) Kurzumtriebsplantagen. Anlage, Pflege, Ernte und Wertschöpfung., DLG-Merkblatt 371, Frankfurt/Main

56. Yue D, You F, Snyder SW (2014) Biomass-to-bioenergy and biofuel supply chain optimization: Overview, key issues and challenges. Comput Chem Eng 66:36-56. doi:10.1016/j.compchemeng.2013.11.016

57. AdV - Arbeitsgemeinschaft der Vermessungsverwaltungen der Länder der Bundesrepublik Deutschland (2008) Amtliches TopographischKartographisches Informationssystem - ATKIS — Objektartenkatalog Basis DLM [Digital Topographic Map of Germany 1:25,000], München

58. LWK - Landwirtschaftskammer Niedersachsen (2000-2015) Landessortenversuche. Feldversuchsdaten, LWK, Hannover. Dataset provided by LWK

59. BMELF - Bundesministerium für Ernährung, Landwirtschaft und Verbraucherschutz (Hrsg.) (1979-2015). Statistisches Jahrbuch über Ernährung, Landwirtschaft und Forsten Landwirtschaftsverlag, Münster-Hiltrup

60. Niedersächsisches Ministerium für Ernährung, Landwirtschaft und Verbraucherschutz (2014) Die niedersächsische Landwirtschaft in Zahlen 2014, Hannover

61. Petzold R, Butler Manning D, Feldwisch N, Glaser T, Schmidt PA, Denner M, Feger KH (2014) Linking biomass production in short rotation coppice with soil protection and nature conservation. iForest Biogeosci Forestry 2014 (7):353-362

62. TLL - Thüringer Landesanstalt für Landwirtschaft (2010) Feldversuchsbericht 2008 und 2009. Ölfrüchte und Nachwachsende Rohstoffe. TLL, Erfurt. http:// www.tll.de/ainfo/archiv/fvb_0310.pdf. Accessed 10 Feb 2015

63. TLL - Thüringer Landesanstalt für Landwirtschaft (2014) Feldversuchsbericht 2012 und 2013. Ölfrüchte und Nachwachsende Rohstoffe. TLL, Erfurt. http:// www.tll.de/ainfo/pdf/fvb_0314.pdf. Accessed 10 Feb 2015 
64. FNR - Fachagentur Nachwachsende Rohstoffe (2012) Energieholzproduktion in der Landwirtschaft., 5. Auflage, Gülzow

65. Wagner $P$, Heinrich J, Kröber M et al (2009) Ökonomische Bewertung von Kurzumtriebsplantagen und Einordnung der Holzerzeugung in die Anbaustruktur Landwirtschaftlicher Unternehmen. In: Bemmann A, Butler Manning $D$ et al (eds) Anbau und Nutzung von Bäumen auf Landwirtschaftlichen Flächen. Wiley-VCH, Weinheim, pp 135-145

66. Kröber M, Heinrich J, Wagner P, Schweinle J (2010) ÖKonomische Bewertung und Einordnung von Kurzumtriebsplantagen in die gesamtbetriebliche Anbaustruktur. In: Bemmann A, Knust C (eds) AGROWOOD - Kurzumtriebsplantagen in Deutschland und europäische Perspektiven. Weißensee, Berlin, pp 325-340

67. Kröber M, Heinrich J, Wagner P, Schweinle J (2013) Betriebswirtschaftliche Bewertung und Vergleich der Wettbewerbsfähigkeit von Kurzumtriebsplantagen mit annuellen Kulturen. In: Bemmann A, Manning B (eds) Energieholzplantagen in der Landwirtschaft: Eine Anleitung zur Bewirtschaftung von schnellwachsenden Baumarten im Kurzumtrieb für den Praktiker. Erling, Berlin, pp 95-105

68. Europäischer Wirtschaftsdienst (EUWID) (2015) Märkte und Preisentwicklungen. http://www.euwid-energie.de/maerkte.html. Accessed: 15 Nov 2015

69. C.A.R.M.E.N. e.V (2015) Wood chips prices. http://www.carmen-ev.de/ infothek/preisindizes/hackschnitzel/jahresmittelwerte. Accessed 15 Nov 2015

70. LWK - Landwirtschaftskammer Niedersachsen (2000-2015). Richtwertdeckungsbeiträge Niedersachsen 2000-2015. Hannover: LWK

71. AMI - Agrarmarkt Informationsgesellschaft mbH (2008-2015) AMI Markt Bilanz. Getreide, Ölsaaten, Futtermittel. Daten, Fakten, Entwicklungen. Deutschland, EU, Welt. AMI, Bonn

72. Bärwolff M, Hering T (2012) Fremdenergiefreie Trocknungsvarianten für Holz aus Kurzumtriebsplantagen. Thüringer Landesanstalt für Landwirtschaft, Jena, Dornburg

73. Wagner K, Staub B, Gersbeck E (2012) Energieholz auf landwirtschaftlichen Flächen - eine betriebswirtschaftliche Analyse. Landwirtschaftszentrum Eichshof, Bad Hersfeld

74. Lenz H, Idler C, Hartung E, Pecenka R (2015) Open-air storage of fine and coarse wood chips of poplar from short rotation coppice in covered piles. Biomass Bioenergy 83:269-277. doi:10.1016/j.biombioe.2015.09.018

75. Kröber M, Heinrich J, Wagner P (2014) Naturschutz und Nutzung Kurzumtriebsplantagen könnten 2015 interessant werden. Bauernblatt 2014(1):47-48

76. KTBL - Kuratorium für Technik und Bauwesen in der Landwirtschaft (2012) Energiepflanzen. Daten für die Planung des Energiepflanzenanbaus., 2A. KTBL, Darmstadt

77. Kröber M, Wagner P (2012) Nachhaltige Landnutzung: Auswirkungen unterschiedlicher Fördermaßnahmen auf die Wirtschaftlichkeit von Kurzumtriebsplantagen. In: Clasen M, Fröhlich G, Bernhardt H, Hildebrand K, Theuvsen B (eds.) Informationstechnologiefür eine nachhaltige Landbewirtschaftung Fokus: Forstwirtschaft LectureNotes in Informatics(LNI) - Proceedings Series of the Gesellschaft für Informatik (GI) Volume P-194, Köllen, Bonn, pp 171-174

78. Hering T (2010) Ertragserwartungen unter Thüringer Standortsbedingungen. Thüringer Landesanstalt für Landwirtschaft, Jena

79. Nahm M, Brodbeck F, Sauter UH (2010) Verschiedene Erntemethoden für Kurzumtriebsplantagen. Ergebnisse aus der Praxis. Forstliche Versuchs- und Forschungsanstalt Baden Württemberg (FVA), Freiburg

80. Burger FJ (2010) Bewirtschaftung und Ökobilanzierung von Kurzumtriebsplantagen. Dissertation Technische Universität München, München

81. Faasch RJ, Patenaude G (2012) The economics of short rotation coppice in Germany. Biomass Bioenergy 45:27-40. doi:10.1016/j.biombioe.2012.04.012

82. Strohm K, Schweinle J, Liesebach M et al (2012) Kurzumtriebsplantagen aus ökologischer und ökonomischer Sicht. Arbeitsberichte aus der vTlAgrarökonomie, Johann Heinrich von Thünen-Institut (vTI), Bundesforschungsinstitut für Ländliche Räume, Wald und Fischerei, Braunschweig

83. Wagner P, Schweinle J, Setzer F et al (2012) DLG-Standard zur Kalkulation einer Kurzumtriebsplantage. Deutsche Landwirtschaftsgesellschaft, Bonn

84. Kröber M, Wagner P (2012) Nachhaltige Landnutzung: Auswirkungen unterschiedlicher Fördermaßnahmen auf die Wirtschaftlichkeit von Kurzumtriebsplantagen. Landwirtschaftliche Betriebslehre, Institut für Agrarund Ernährungswissenschaften Martin-Luther-Universität HalleWittenberg,06099, Halle/Saale
85. Bärwolff M, Hansen H, Hofmann M, Setzer F (2012) Energieholz aus der Landwirtschaft, 5th edn. FNR - Fachagentur für nachwachsende Rohstoffe, Gülzow

86. Belau T, Döhler H, Eckel H et al (2012) Energiepflanzen: Daten für die Planung des Energiepflanzenanbaus, 2nd edn. Kuratorium für Technik und Bauwesen in der Landwirtschaft, Darmstadt

87. Kaiser, Steffen. "Wirtschaftlichkeit von KUP." presented at the Praxistag Kurzumtriebsplantagen, Kandel, February 29, 2012. Internet source: http://www.ltz-bw.de/pb/site/pbs-bw-new/get/documents/MLR.LEL/ PB5Documents/ltz_ka/Service/Neranstaltungen/Nachlese/2012/2012_02_29KUP-Praxistag_DL/Praxistag\%20KUP\%202012\%20-Kaiser\%20\%20Wirtschaftlichkeit\%20von\%20KUP.pdf. Accessed 12 Dec 2015.

88. von Behr W, Bemmann A, Michalk K et al (2012) Kurzumtriebsplantagen. Anlage, Pflege, Ernte und Wertschöpfung. DLG-Merkblatt (371). DLG Deutsche Landwirtschaftsgesellschaft, Frankfurt/Main

89. Wolbert-Haverkamp M (2012) Miscanthus and poplar plantations in short rotation as an alternative to classical crop husbandry-a risk analysis by means of Monte Carlo simulation. Berichte über Landwirtschaft 90:302-316

90. Schweier J, Becker $\mathrm{G}$ et al (2012) Harvesting of short rotation coppice-harvesting trials with a cut and storage system in Germany. Silva Fennica 46:287-299

91. Hering T, Reinhold G, Biertümpfel A, Vetter A (2013) Leitlinie zur effizienten und umweltverträglichen Erzeugung von Energieholz, 4th edn. Thüringer Landesanstalt für Landwirtschaft, Jena

92. Schweier J, Becker G (2013) Economics of poplar short rotation coppice plantations on marginal land in Germany. Biomass Bioenergy 59:494-502. doi:10.1016/j.biombioe.2013.10.020

93. Schweier J (2013) Erzeugung von Energieholz aus Kurzumtriebsplantagen auf landwirtschaftlichen Marginalstandorten in SüdwestdeutschlandUmweltbezogene und ökonomische Bewertung alternativer Bewirtschaftungskonzepte unter besonderer Berücksichtigung verschiedener Holzernteverfahren. Verlag Dr. Hut, Freiburg

94. Ehlert D, Pecenka R (2013) Harvesters for short rotation coppice: current status and new solutions. Int J For Eng 24:170-182. doi:10.1080/14942119. 2013.852390

95. Hauk S, Knoke T, Wittkopf S (2014) Economic evaluation of short rotation coppice systems for energy from biomass - a review. Renew Sustain Energy Rev 29:435-448. doi:10.1016/j.rser.2013.08.103

96. Schuler J (2014) Instrumente zur Stärkung von Synergien zwischen Naturund Klimaschutz im Bereich Landbewirtschaftung: Ergebnisse des F+EVorhabens (FKZ 351188 0200) "Stärkung von Synergien zwischen Naturschutz und Klimaschutz im Bereich Landbewirtschaftung. BfN Bundesamt für Naturschutz, Bonn-Bad Godesberg, Deutschland

97. Becker R, Röhricht C, Ruscher K, Jäkel K (2014) Schnellwachsende Baumarten im Kurzumtrieb-Anbauempfehlungen. Sächsisches Landesamt für Umwelt, Landwirtschaft und Geologie, Dresden

98. Pecenka R, Lenz H, Idler C et al (2014) Development of bio-physical properties during storage of poplar chips from 15 ha test fields. Biomass Bioenergy 65:13-19

99. Anonymous (2015) Trocknung von Energieholz und Getreide mit BiogasWärme. C.A.R.M.E.N - Centrale Agrar-Rohstoff Marketing- und EnergieNetzwerk, Straubing

100. Busch G (2017) BEAST - A decision support tool for a regional stakeholder dialogue on climate protection and sustainable land use - Tool description and case study results. IEA Bioenergy Task43, Report. [Under Review]

101. Eder M (1993) Risikoanalyse mit Hilfe der Stochastischen DominanzFallbeispiel mit Versuchsdaten ausgewählter Marktfrüchte. Die Bodenkultur 44(3):275-288

102. Maart-Noelck SC, Musshoff O (2014) Measuring the risk attitude of decisionmakers: are there differences between groups of methods and persons? Aust J Agric Resour Econ 58:336-352

103. Müller U, Waldeck A (2011) Auswertungsmethoden im Bodenschutz. Dokumentation zur Methodenbank des Niedersächsischen Bodeninformationssystems (NIBIS ${ }^{\oplus}$ ), vol 19. Geo-Berichte, Landesamt für Bergbau, Energie und Geologie, Hannover

104. DIN 19708 (2005) Bodenbeschaffenheit-Ermittlung der Erosionsgefährdung von Böden durch Wasser mit Hilfe der ABAG. Beuth Verlag, Berlin

105. Renard KG, Foster GR, Weesies G, McCool D, Yoder D (1997) Predicting soil erosion by water: a guide to conservation planning with the Revised Universal Soil Loss Equation (RUSLE). US Government Printing Office, Washington 
106. Schäfer W, Sbresny J, Thiermann A (2010) Methodik zur Einteilung von landwirtschaftlichen Flächen nach dem Grad ihrer Erosionsgefährdung durch Wasser gemäß §2 Abs. 1 der Direktzahlungen-Verpflichtungenverordnung in Niedersachsen. Niedersächsisches Landesamt für Bergbau, Energie und Geologie (LBEG), Geozentrum Hannover, Hannover

107. Seidel D, Busch G, Krause B et al (2015) Quantification of biomass production potentials from trees outside forests - a case study from Central Germany. Bioenergy Res 8:1344-1351. doi:10.1007/s12155-015-9596-z

108. Ericsson K, Rosenqvist H, Nilsson LJ (2009) Energy crop production costs in the EU. Biomass Bioenergy 33:1577-1586

109. EU - European Union (2009) Council Regulation (EC) No 73/2009 of 19 January 2009 establishing common rules for direct support schemes for farmers under the common agricultural policy and establishing certain support schemes for farmers, amending regulations (EC) No 1290/2005, (EC) No 247/2006, (EC) No 378/2007 and repealing Regulation (EC) No 1782/2003

110. Rinner C, Malczewski J (2002) Web-enabled spatial decision analysis using ordered weighted averaging (OWA). J Geogr Syst 4:385-403

111. Malczewski J, Rinner C (2005) Exploring multicriteria decision strategies in GIS with linguistic quantifiers: a case study of residential quality evaluation. J Geogr Syst 7:249-268. doi:10.1007/s10109-005-0159-2

112. Jedicke E (1994) Biotopverbund. Grundlagen und Maßnahmen einer neuen Naturschutzstrategie. Ulmer, Stuttgart

113. Jennemann L, Peters W, Rosenthal S, Schöne F (2011) Naturschutzfachliche Anforderungen für Kurzumtriebsplantagen. Praktische Umsetzung von Maßnahmen bei der Neuanlage und Bewirtschaftung von Energieholzflächen (Voruntersuchung). NABU-Bundesverband und Bosch \& Partner GmbH, Berlin, https://www.bfn.de/fileadmin/MDB/documents/ themen/erneuerbareenergien/Publikationen_EuE/kup-anforderungen.pdf. Accessed 20 Apr 2015

114. Frank S (2014) Development and validation of a landscape metrics based approach for standardized landscape assessment considering spatial patterns. TU Dresden, Germany, Dissertation

115. Herzig A (2006) Entwicklung eines GIS-basierten Entscheidungsunterstützungssystems als Werkzeug nachhaltiger Landnutzungsplanung. Christian-Albrechts-Universität Kiel, Germany, Dissertation

116. Köstner B, Eitzinger J (eds) 2014: Land, climate and resources 2020. Decision Support for Agriculture under Climate Change. Eur J Agron. 52, Part A, 1-80

117. von Haaren C, Kempa D, Vogel K, Rüter S (2012) Assessing biodiversity on the farm scale as basis for ecosystem service payments. J Environ Manage 113:40-50. doi:10.1016/j.jenvman.2012.07.033

118. Bauböck R (2014) Simulating the yields of bioenergy and food crops with the crop modelling software BioSTAR: the carbon-based growth engine and the BioSTAR ET 0 method. Environ Sci Eur 26:1

119. Malczewski J (2004) GIS-based land-use suitability analysis: a critical overview. Prog Plan 62:3-65

120. Ehrgott M (2006) Multicriteria optimization. Springer Science \& Business Media, Berlin

121. Wolbert-Haverkamp M, Musshoff O (2014) Are short rotation coppices an economically interesting form of land use? A real options analysis. Land Use Policy 38:163-174. doi:10.1016/j.landusepol.2013.10.006

122. Frank S, Fürst C, Koschke L, Makeschin F (2012) A contribution towards a transfer of the ecosystem service concept to landscape planning using landscape metrics. Ecol Indic 21:30-38. doi:10.1016/j.ecolind.2011.04.027

123. Frank S, Fürst C, Witt A et al (2014) Making use of the ecosystem services concept in regional planning - trade-offs from reducing water erosion. Landsc Ecol 29:1377-1391. doi:10.1007/s10980-014-9992-3

\section{Submit your manuscript to a SpringerOpen ${ }^{\circ}$ journal and benefit from:}

- Convenient online submission

- Rigorous peer review

- Immediate publication on acceptance

- Open access: articles freely available online

- High visibility within the field

Retaining the copyright to your article

Submit your next manuscript at $\gg$ springeropen.com 